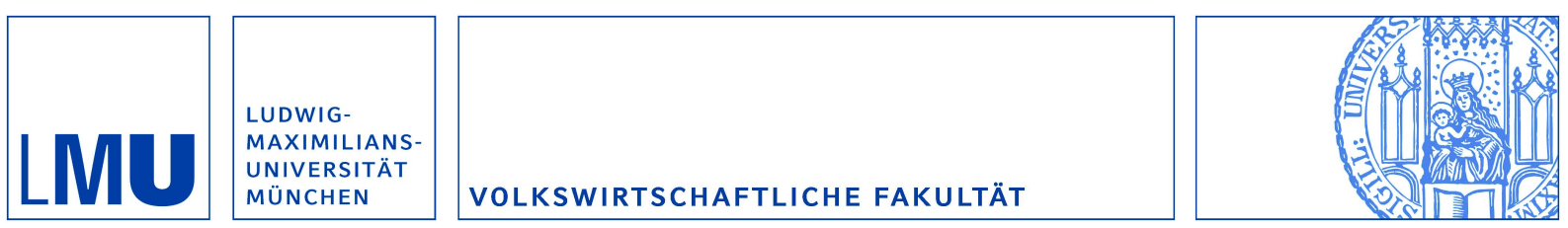

Dischinger, Matthias and Riedel, Nadine:

There's No Place Like Home: The Profitability Gap between Headquarters and their Foreign Subsidiaries

Munich Discussion Paper No. 2009-13

Department of Economics

University of Munich

Volkswirtschaftliche Fakultät

Ludwig-Maximilians-Universitä† München

Online at https://doi.org/10.5282/ubm/epub. 10976 


\title{
There's No Place Like Home: The Profitability Gap between Headquarters and their Foreign Subsidiaries
}

\author{
Matthias Dischinger* \\ University of Munich
}

\author{
Nadine Riedel ${ }^{\dagger}$ \\ University of Oxford and CESifo Munich
}

Version: August 26, 2009

\begin{abstract}
Using a large panel data set for European firms, this paper provides evidence that operations at multinational headquarters are significantly more profitable than operations at their foreign subsidiaries. The effect turns out to be robust and quantitatively large. Our findings suggest that the profitability gap is partly driven by agency costs which arise if value-driving functions are managed by a subsidiary that is geographically separated from the headquarters management. In line with falling communication and travel costs over the last decade, the profitability gap is shown to decline over time. Apart from that, our results indicate that a higher competitiveness of multinational firms in their home markets also contributes to the profitability gap. We discuss various implications of our findings.
\end{abstract}

JEL classification: L25, D82, F23, H25

Keywords: profitability distribution, multinational enterprise, corporate taxes

*Department of Economics, University of Munich, Akademiestr. 1/II, 80799 Munich, Germany, phone: +49-89-2180-2279, e-mail: dischinger@lmu.de

${ }^{\dagger}$ Oxford University Centre for Business Taxation, Saïd Business School, Park End Street, Oxford, OX1 1 HP, e-mail: nadine.riedel@sbs.ox.ac.uk

We are indebted to Johannes Becker, Ronald Davis, Michael Devereux, Clemens Fuest, Andreas Haufler, Harry Huizinga, Joel Slemrod, Johannes Voget and to participants of the Zeuthen Workshop at the University of Copenhagen, the workshop Taxes $\&$ the Financial \& Legal Structure of Firms at the University of Vienna, the CESifo Public Sector Conference and seminars at the Universities of Munich, Tilburg and Dublin for helpful comments. Financial support of the German Research Foundation (DFG) is gratefully acknowledged. 


\section{Introduction}

The purpose of this paper is to compare the profitability of corporate activities at multinational headquarters and their foreign subsidiaries. Although the emergence and investment behavior of multinational enterprises (MNEs) are well studied (see e.g. Barba-Navaretti and Venables, 2006; Brakman and Garretsen, 2008), the literature has so far largely neglected to investigate the profit distribution within multinational groups. Exceptions are recent public finance papers which suggest that multinational profits tend to be distorted towards affiliates with a low corporate tax rate as MNEs shift paper profits from high-tax to low-tax entities and tend to bias the location of profitable investment projects in favor of low-tax affiliates (e.g. Devereux and Maffini, 2007; Huizinga and Laeven, 2008; Dischinger and Riedel, 2008; Becker, Fuest, and Riedel, 2009).

Our paper adds to this literature by testing whether the profitability of headquarters activities statistically differs from activities undertaken at foreign subsidiaries. To the best of our knowledge, we are the first study to empirically investigate this question although a set of existing theoretical papers (implicitly) suggests that headquarters activities exhibit a higher profitability than operations located at multinational subsidiaries. One strand of papers which is related to the notion of "vertical" foreign direct investment (FDI) proposes that this pattern arises due to agency costs faced by the headquarters management if valuable assets and functions are located with geographically separated subsidiaries (see e.g. Chang and Taylor, 1999; Hamilton and Kashlak, 1999; O'Donnell, 2000). An alternative explanation for the headquarters bias is brought forward by the theoretical literature on "horizontal" FDI which suggests that investments at the parent location may exhibit a higher profitability because MNEs have advantages when operating in their home market as they know the language, culture and customs better than foreign competitors (see e.g. Dunning, 1977; Brakman and Garretsen, 2008).

To test for the profitability gap between headquarters and their foreign subsidiaries, we exploit a large European firm data set which is available for the years 1999 to 2006. Our results indicate that the profitability of headquarters investments indeed largely outweighs the profitability of investments at foreign subsidiaries. Our most conservative estimates quantify the profitability gap with around $30 \%$. The results turn out to be robust against the use of different profitability measures and the inclusion of a large set of control variables: multinational group fixed effects (to account for unobserved heterogeneity between MNEs), country fixed effects (to control for productivity differences 
between countries), industry fixed effects, the size of the input factors, the corporate leverage and firm age (to account for set up costs faced by young corporations).

Moreover, we test how the profit gap has evolved over time. If profitability differences between headquarters and their foreign subsidiaries were driven by agency costs, one would presume that the profitability gap has declined in the last decade as new technological developments, like the invention of the internet and mobile phone, have led to reductions in communication and monitoring costs. Although the predictions for the home market effect are less clear cut, a similar pattern might arise. Interestingly, our data indeed suggests a significant drop in the parent bias by at least 1.5 percentage points per year, implying that the profitability gap has closed by at least $15 \%$ over our sample period (1999-2006) whereas some specifications point to a closure of the gap by more than $30 \%$.

Following these baseline estimates, we additionally assess whether and to what extent agency costs and the home market effect contribute to the profitability gap. To do so, we distinguish between "vertical" and "horizontal" FDI as the agency costs argument is mainly tied to the former while the home market advantage argument is largely tied to the latter. Thus, we divide the sample in two subgroups, the first comprising multinationals where the parent firm and the observed subsidiary operate in the same 4-digit NACE industry (proxying for horizontal FDI) and the second comprising multinationals where the parent firm and the observed subsidiary operate in different 4-digit NACE industries (proxying for vertical FDI). The profitability gap between parents and subsidiaries prevails in both groups suggesting that agency costs and the home market effect play a role in driving the results. Moreover, we find that the profitability gap closes over time in the vertical FDI group (in line with the notion of falling communication and agency costs) while the effect remains constant in the horizontal FDI-group.

Furthermore, we run a large set of robustness checks. Most importantly, we assess whether the profitability gap derived in this paper is unique to the international context or whether it prevails in national groups. Our estimations indicate a statistically significant profitability gap between headquarters and their domestic subsidiaries that is measured to be around one third of the gap derived in our baseline specifications. In additional sensitivity checks, the paper among others shows that the derived profitability pattern is not driven by mergers \& acquisitions (M\&A) and does not reflect avoidance of dividend withholding taxes.

In a last step, we discuss potential implications of the presented parent bias for eco- 
nomic welfare and public economic policy. Profitability is expected to affect a country's welfare along several lines. It for example determines the size of the firm's corporate tax payments and thus, our analysis suggests that parent firms pay higher taxes on their corporate activity than subsidiaries. This presumption is confirmed in our data. Conditioning on affiliate size and the host country's corporate tax rate, tax payments at multinational headquarters are found to be $60 \%$ larger than the tax payment at their multinational subsidiaries. In a companion paper (Dischinger and Riedel, 2009), we moreover show that multinational firms are reluctant to shift profits and profitable assets away from the headquarters firm in response to corporate tax rate differentials. Additionally, affiliate profitability is well known to positively affect local wage bargaining outcomes and consequently, workers at the headquarters firm are predicted to earn larger wages than their colleagues at the subsidiary level (see e.g. Budd, Konings, and Slaughter, 2005). Thus, our paper suggests that countries tend to profit more from hosting a multinational headquarters firm than from hosting a multinational subsidiary. This may, for example, rationalize government policies to create national champions by intervening in international M\&A activities. But our results also in a broader sense suggest that it is in the national interest of economic policy to strengthen the domestic parent firms rather than trying to attract subsidiaries from abroad.

The paper is structured as follows. In Section 2, we provide a theoretical motivation for our analysis, Section 3 describes our data set. In Section 4, we present our estimation methodology and in Section 5 the estimation results. Section 6 discusses implications of our findings and Section 7 concludes.

\section{Theoretical Considerations}

The purpose of this paper is to test whether the profit distribution of multinational firms is skewed in favor of the headquarters location. There are two strings of the literature which suggest a positive profitability gap between parent firms and their subsidiaries: the first proposes agency costs to give rise to a higher profitability of headquarters investment, while the second suggests that the same pattern is induced by home market advantages.

The agency cost theory is related to the notion of "vertical" FDI, i.e. the presumption that value chains comprising various functions like manufacturing, logistics, marketing and R\&D are geographically separated across borders. Recent contributions brought forward empirical evidence for this kind of vertical fragmentation (see Campa and 
Goldberg, 1997; Hummels, Rapoport, and Yi, 1998; Hummels, Ishii, and Yi, 2001; Hanson, R. J. Mataloni, and Slaughter, 2001; Hanson, R. J. Mataloni, and Slaughter, 2005). Assuming that the profitability of functions within the value chain differs, the MNE may strategically choose the location of profit-driving operations. ${ }^{1}$ Several papers in the business economics literature suggest that MNEs have a tendency to keep valuable functions with the head office as physical distance hampers communication and the headquarters management thus faces agency and information costs if these operations are run abroad (see e.g. Chang and Taylor, 1999; Hamilton and Kashlak, 1999; O'Donnell, 2000). ${ }^{2}$ Nevertheless, the last decade was also characterized by the development of new technologies like the internet and the mobile phone which have lowered communication costs and might henceforth have dampened agency problems caused by geographic separation (see e.g. Freund and Weinhold, 2002, Blinder, 2006). This suggests that the profitability gap is not constant over time but has declined in recent years.

A second literature strand proposes that the profitability gap between headquarters and their foreign subsidiaries may be induced by a different mechanism which is related to the notion of "horizontal" FDI. Precisely, the papers suggest that exporting the MNE's business model and products to foreign countries by setting up production and sales units there may result in lower profitability rates since these units may for example have less knowledge about language, customs and consumer behavior than their domestic competitors or since the MNE's products might have been developed to fit domestic not foreign consumer preferences (e.g. Dunning, 1977; Brakman and Garretsen, 2008). ${ }^{3}$

\footnotetext{
${ }^{1}$ Some contributions suggest that the functions which drive the corporate profit are knowledge and marketing related, like R\&D and advertisement (see e.g. Zingales, 2000).

${ }^{2}$ Furthermore, La Porta, de Silanes, and Shleifer (1999), analyze the widespread organizational form of corporate pyramids which are strongly associated with agency problems.

${ }^{3}$ Note that two other mechanisms may give rise to a profitability bias in favor of the parent firm. Firstly, Betrand, Mehta, and Mullainathan (2002) show that business groups expropriate minority shareholders by tunneling profits from firms where they have low cash flow rights (e.g. subsidiaries owned by less than $100 \%$ of the ownership shares) to firms where they have high cash flow rights (e.g. the headquarters firm). However, as our empirical analysis compares parent firms and their whollyowned subsidiaries, this motive is not considered in our empirical analysis. Secondly, MNEs may have an incentive to bias the location of profits towards the parent firm in order to save withholding taxes on dividend payments which become due upon repatriation. As withholding taxes on dividends are however low within the European Union, we consider this to be unlikely which is empirically confirmed in a robustness check.
} 
In the following, we will bring these hypotheses to the data and test whether operations located at the headquarters firm are indeed more profitable than operations located at foreign subsidiaries. Moreover, we will assess the role of agency costs and the home market effect in generating this profitability pattern.

\section{Data}

Our empirical analysis relies on the commercial database AMADEUS which is compiled by Bureau van Dijk. The version of the database available to us contains detailed information on firm structure and accounting of national and multinational corporations in Europe. We focus on 27 European countries ${ }^{4}$ and on the time period of 1999 to 2006 as these countries and years are sufficiently represented by the database. One major advantage of AMADEUS is that it allows to link accounting information for parent firms and their corporate subsidiaries which makes the data set ideal for our purpose.

For an observation to be included in the sample, it has to belong to an MNE. The parent firms in our sample are the global ultimate owner of a multinational group and own at least one subsidiary in a foreign country with an ownership share of $100 \%$. The subsidiaries in our sample likewise belong to a multinational group in the sense that they are wholly owned by a parent corporation in a foreign country. The subsidiaries may own (further) subsidiaries themselves whereas this is not decisive for our qualitative results. The country statistics for the parent and subsidiary sample are presented in Table 1.5

[Table 1 here]

Moreover, in our baseline regressions we restrict the sample to firms which earn a positive pre-tax profit since our theoretical considerations apply particularly well to firms with a positive profit and this allows us to abstract from loss-offset regulations. Additionally, it enables us to take the logarithm of the pre-tax profitability as the dependent variable which is suggested since the variable exhibits a rather skewed dis-

\footnotetext{
${ }^{4}$ Austria, Belgium, Bulgaria, Croatia, Czech Republic, Denmark, Estonia, Finland, France, Germany, Great Britain, Hungary, Ireland, Italy, Latvia, Luxembourg, Netherlands, Norway, Poland, Portugal, Romania, Serbia, Slovakia, Spain, Sweden, Switzerland, Ukraine.

${ }^{5}$ Note that subsidiaries from Ireland and Switzerland could not be included in the analysis as the cost of employees information is missing in all cases.
} 
tribution. However, in robustness checks we reran our regressions including firms with negative pre-tax profits and did not find qualitatively different results.

The observational unit in our analysis is the multinational affiliate, i.e. the parent or subsidiary firm per year. In total, our baseline sample comprises 107, 930 observations from 25,393 affiliates for the years 1999 to 2006 belonging to 18,531 multinational groups. $49.1 \%$ of the observations are parent firms. This number may seem surprisingly high but simply reflects the fact that our data does not only comprise corporate groups for which both, the parent firm and at least one corporate subsidiary, are available but also MNEs for which either one or the other is observed. Since many firms in our data are parents with subsidiaries outside of Europe (which then are not covered by AMADEUS), the fraction of parent firms in our sample is quite large.

As our analysis will include fixed effects for the multinational group, the parent bias is identified via the former set of groups only which accounts for 57, 261 observations. The rationale for equally keeping the other firms in the sample is that the coefficient estimates of all other control variables are predicted to be econometrically more precise. However, as a robustness check, we reran our regressions on the sub-sample of firms for which parent and subsidiary information is available and found our qualitative and quantitative results to be confirmed. Note moreover that in this sub-sample of multinational groups the fraction of parent firms is estimated to be a moderate $23.5 \%$. Furthermore, to control for country characteristics, we merge data on GDP, GDP per capita, a corruption index and the statutory corporate tax rate to the firm accounting data. ${ }^{6}$ Table 2 displays basic descriptive sample statistics.

[Table 2 here]

On average, the affiliates in our sample observe a pre-tax profit of 18.6 million US dollars, fixed asset investments of 154.3 million and sales of 191.9 million US dollars. The average firm employs 565 workers. The median of the distributions is substantially smaller for all three variables. The median for the profitability measures gross profit margin (i.e. pre-tax profit over sales) and EBIT margin (i.e. earnings before interest and tax over sales) is estimated with $5.85 \%$ and $5.76 \%$ respectively. Note, moreover that the sample characteristics substantially differ between parent firms and subsidiaries.

\footnotetext{
${ }^{6}$ The statutory tax rate data is taken from the European Commission. Country data for GDP and GDP per capita are obtained from the IMF World Economic Outlook Database October 2008. The Corruption Perceptions Index is taken from Transparency International and ranks from 0 (extreme level of corruption) to 10 (free of corruption).
} 
First, parent firms tend to be larger than their subsidiaries with an average fixed assets stock of 285.4 million US dollars and a median of 8.61 million versus an average fixed asset stock of 27.7 million and a median of 0.60 million US dollars at the subsidiary level. Additionally, the descriptive statistics already suggest a profitability gap between parents and their subsidiaries as the median of the gross profit margin and EBIT margin at the parent level is $6.39 \%$ and $6.05 \%$ respectively, while the median of these ratios at the subsidiary level is calculated with $5.43 \%$ and $5.49 \%$ respectively. The next section will investigate whether these descriptive patterns prevail in an econometric framework.

\section{Estimation Approach}

Following our theoretical considerations in Section 2, we estimate an empirical model of the following form

$$
\log \pi_{i j t}=\beta_{0}+\beta_{1} P A R E N T_{i j t}+\beta_{2} X_{i j t}+\phi_{j}+\rho_{t}+\epsilon_{i j t}
$$

whereas $\pi_{i j t}$ represents the profitability measure of affiliate $i$ belonging to multinational group $j$ at time $t$. We employ two profit variables which are taken from the firms' unconsolidated balance sheet information: profit before tax (PBT) and earning before interest and tax (EBIT). While PBT captures the overall affiliate profit (comprising operating and financial profits), the EBIT measure depicts the firm's operating profit. In the following, we will determine the profitability gap between parents and their subsidiaries in terms of both variables. Moreover, since the profit variables exhibit a rather skewed distribution (cf. e.g. the divergence of mean and median in Table 2), we employ a logarithmic transformation.

The explanatory variable of central interest is $P A R E N T_{i j t}$ which depicts a dummy that takes on the value 1 if the considered affiliate is an independent parent firm and the value 0 if it is a dependent subsidiary. Our theoretical considerations suggest that the profitability of assets at the parent firm exceeds the profitability of assets at the subsidiary and henceforth, $\beta_{1}>0$. In the contrary, if neither agency costs nor the home market effect play a decisive role, we expect $\beta_{1}=0$. Our regressions moreover control for a set of subsidiary and country characteristics depicted by the vector $X_{i j t}$. Precisely, we condition on the size of the multinational affiliate by including the entity's capital investment and payroll $\operatorname{costs}^{7}$ and furthermore account for affiliate age to acknowledge that young firms entering a market may face additional costs.

\footnotetext{
${ }^{7}$ Note that including the affiliate's payroll bill as an explanatory variable controls for both differences in the wage rate as well as differences in the skill level and productivity of the affiliates'
} 
Moreover, we include a full set of fixed effects for the multinational group to control for non-observable, MNE specific characteristics $\phi_{j}$ which may determine the profitability of all affiliates within the group. While the use of a group fixed-effects model is generally suggestive in our context, it is also preferred to a random effects model by a Hausman-Test. Furthermore, year dummies $\rho_{t}$ are included to capture shocks over time which are common to all affiliates. Additionally, we account for a full set of country dummies. These absorb time-constant country characteristics, for example, differences in the education and skill level or differences in accounting laws which may translate into differing reported profitability levels. Apart from that, we also include different time-varying macro controls which may exert an impact on affiliate profitability (GDP as a proxy for the market size, GDP per capita as a proxy for the degree of development of a country, an index of corruption as a proxy for the overall risk of a country and the statutory corporate tax rate as a proxy for the corporate tax burden). $\epsilon_{i j t}$ describes the error term.

\section{$5 \quad$ Estimation Results}

The following section presents the results for the estimation model specified above. Section 5.1 discusses our baseline regressions. Section 5.2 investigates the development of the profitability gap over time. Section 5.3 assesses the role of agency costs and the home market effect in driving the results and Section 5.4 discusses various robustness checks. Throughout the analysis, the observational unit is the multinational affiliate per year. All regressions include a full set of group fixed effects and year fixed effects. The result tables display the coefficient estimates and, in parentheses, heteroscedasticity robust standard errors which are adjusted for clustering at the level of the multinational group.

\subsection{Baseline Estimations}

Tables 3 and 4 present our baseline estimations. In Table 3, we estimate equation (1) employing the affiliate's pre-tax profit and EBIT measure as dependent variable. In Specification (1), we regress the affiliate's pre-tax profit on a parent dummy and control variables for the input factors, a full set of group fixed effects and year fixed effects.

workers. Note moreover that we also reestimate equation (1) accounting for an additional size control by normalizing on a sales factor, i.e. by employing the affiliate's gross profit margin (=PBT per sales) and EBIT margin (=EBIT per sales) as dependent variables. 
As predicted by our theoretical considerations, the coefficient estimate for the parent dummy exhibits a positive sign and is statistically significant at the $1 \%$ level. Quantitatively, multinational parent firms are suggested to observe a level of pre-tax profits which is by $88 \%$ larger than the pre-tax profits of their subsidiaries. This qualitative result is robust against the inclusion of a full set of country fixed effects and timevarying country characteristics (GDP, GDP per capita, corruption index and statutory corporate tax rate) in Specification (2), the affiliate's debt-to-assets ratio in Specification (3) and a set of two-digit NACE code industry dummy variables in Specification (4). Adding these additional control variables reduces the size of the coefficient estimates for the parent dummy. Specification (4) suggests that (conditioning on the input factors and the other control variables) parent firms observe pre-tax profits which are by $65 \%$ larger than profits at their corporate subsidiaries. ${ }^{8}$

\section{[Table 3 here]}

In a second step, we re-estimate the regressions presented in Columns (1) to (4) using EBIT as the dependent variable and thus determining differences in the operating profitability between parents and their subsidiaries. The results are presented in Columns (5) to (8) and qualitatively resemble the results for the pre-tax profit measure although the point estimates of the parent effect are quantitatively smaller. Column (8) suggests that (conditioning on the input factors and all other control variables) operating profits at the parent firm are on average by $43 \%$ larger than operating profits at its subsidiaries.

Note that in all specifications the coefficient estimates for the control variables exhibit the expected sign. The corporate input factors, fixed assets investments and cost of employees, enter positively and are statistically significant suggesting that the production displays decreasing returns to scale as the coefficient estimates add up to less than 1 . The leverage ratio has a significant and negative effect on the affiliate's profit level which reflects that highly leveraged firms are more dependent on creditors and are therefore restricted with respect to the riskiness of their projects which results in lower expected profitability rates. Moreover, the host country's GDP per capita impacts positively on firm profits as does a low level of corruption (note that a high corruption index stands for a low level of corruption). The coefficient estimate for the statutory corporate tax rate exhibits a negative sign which is commonly interpreted to reflect

\footnotetext{
${ }^{8}$ Note moreover that the adjusted $R^{2}$ in all specifications is high, between $79.3 \%$ and $80.4 \%$, increasing with the set of additional control variables.
} 
profit shifting activities from high-tax to low-tax locations. A country's GDP exerts a significantly negative impact in the EBIT specifications which may reflect that a higher degree of competition in larger consumer markets depresses operating profits.

[Table 4 here]

In Table 4, we re-estimate the specifications presented in Table 3 adding another size control by normalizing the specifications on affiliate sales. Thus, we regress the gross profit margin (= pre-tax profit/sales) and the EBIT margin(=EBIT/sales) on a set of control variables comprising the input factors per sales and a size control. The results are depicted in Table 4 and confirm our previous findings as they indicate a large and statistically significant parent bias. Column (4) suggests that after controlling for input factors, the firm leverage, macro characteristics and fixed year, country, industry and MNE-group effects, parent firms are by $65 \%$ more profitable than their subsidiaries in terms of the gross profit margin. Column (5) to (8) re-estimate the specifications using the EBIT margin as the dependent variable and find comparable, although somewhat smaller, coefficient estimates. The most conservative estimate in Column (8) suggests a profitability gap of $30 \%$. We additionally experimented with other profitability measures which imply the normalization of equation (1) on an affiliate's total assets and its number of employees respectively. These regressions show comparable results which are available from the authors upon request.

\subsection{Development over Time}

Thus, our baseline analysis provides evidence for a significant and quantitatively relevant parent bias in the location of profitable operations across multinational affiliates. As discussed above, this effect is however not necessarily constant over time. If agency costs contribute to the profitability gap between parents and their corporate subsidiaries, one might presume that the profitability gap has declined in the past decade since the rise of new technologies has facilitated communication and information exchange and has consequently lowered agency costs for monitoring operations at geographically separated affiliates. The same pattern might to some extent also prevail if the home market effect drives the profitability gap since markets in the EU have become more open and a proceeding integration may have enlarged the knowledge of local customs and consumption behavior. 
[Table 5 here]

To empirically assess this hypothesis, we interact our parent dummy variable with a linear time trend. ${ }^{9}$ The results are presented in Table 5. In Column (1), we regress the pre-tax profit measure on the parent dummy and the time trend interaction. In line with our presumption, the coefficient estimate for the parent dummy exhibits a positive sign and is statistically significant while the coefficient estimate for the interaction term between the parent dummy and the time trend exhibits a significantly negative sign. Consequently, while in our first sample year 1999 parents observe a pre-tax profit (conditioned on the input factors) which is about twice as large as the pre-tax profit at their subsidiaries, this profitability gap closes by around 2.4 percentage points in each of the successive years. This corresponds to a closure of the profitability gap by $17 \%$ in our 7 -year sample period. This result is confirmed when we account for additional control variables in Specification (2) or alternative profitability measures in Specifications (3) to (8). Note that in terms of the EBIT margin (Column (7) and (8)), the decline in the profitability gap is reported to be quantitatively even more pronounced since the profitability gap between the parent and the subsidiary closes by $37 \%$ or 13.3 percentage points from its initial level of $36 \%{ }^{10}$

\subsection{A Closer Look: Agency Costs and Home Market Effect}

As described in Section 2, we presume that the profitability gap between headquarters and their subsidiaries may be driven by agency costs or home market advantages. The aim of the following section is to get an idea whether and to what extent the two mechanisms contribute to the profitability gap.

To disentangle the role of agency costs and the home market effect, we split the sample in "horizontal" and "vertical" foreign direct investments. As described in Section 2, the agency costs theory largely relates to the notion of "vertical" FDI as the argument refers to the location choice of different operations in the multinational value chain that may vary in their corporate profitability. In the contrary, the home market effect

\footnotetext{
${ }^{9}$ The linear time trend variable takes on the value 0 for our first sample year 1999, the value 1 for the second sample year and so on.

${ }^{10}$ As a sensitivity check, we interacted the parent dummy variable with a dummy for each sample year. All coefficient estimates exhibit a negative sign and smoothly grow in absolute size over time which suggests a steady decline of the profitability gap in our sample period. The results are available from the authors upon request.
} 
largely relates to the notion of "horizontal" FDI as it discusses potential profitability differences in selling the same product on different markets. To identify "horizontal" and "vertical" investment in our sample, we exploit four-digit NACE industry information on the parent and its corporate subsidiaries. Precisely, if the subsidiary operates in the same four-digit NACE industry as the parent firm, it is classified as "horizontal" FDI whereas it is considered "vertical" FDI if it operates in a different four-digit industry. Consequently, we run two sets of regressions: one, in which we include only subsidiaries that observe the same four-digit NACE industry as their parent, and a second, in which we include only subsidiaries that observe a different four-digit industry than their parent. The results are presented in Table 6. Specifications (1) and (2) re-estimate our baseline regressions for the two sub-groups employing the profit before taxation (PBT) measure as dependent variable. The coefficient estimate for the parent dummy variable is positive and statistically significant in both samples indicating that the profitability gap between headquarters firms and their subsidiaries prevails in horizontal investment settings as well as in vertical investment settings. Thus, we may conclude that our sample indicates that both, home market advantages and agency costs drive a wedge between the profitability of headquarters and subsidiaries (whereas the impact of the former appears to be quantitatively larger).

[Table 6 here]

In Specifications (3) and (4), we interact the parent dummy with a linear time trend following our analysis in the previous section. Interestingly, we find that the size of the profitability gap between headquarters and subsidiaries remains constant over time in the sample accounting for horizontal subsidiaries (and the home market effect respectively) while it significantly declines in the sample accounting for vertical subsidiaries (and the agency costs theory respectively). In the context of our theoretical presumptions, this suggests that technological advances have indeed induced a fall in agency costs over the last decade while advantages of operating in home markets have remained largely unchanged. ${ }^{11}$ Finally, we reestimate the presented PBT-regressions

\footnotetext{
${ }^{11} \mathrm{~A}$ third mechanism which may drive the profitability gap between parents and their subsidiaries and has not yet been discussed in the paper is that MNEs potentially bias the distribution of their profits in favor of the headquarters firm to save withholding taxes on dividend payments from subsidiaries to their parent. However, as the withholding taxes on dividends have been low between EU countries over the last decades and were abolished through the EU's Parent-Subsidiary Directive in 2004, we consider this to be an unlikely scenario. Nevertheless, as a robustness check we reran our regressions excluding all subsidiary-year combinations from our sample which face a non-zero with-
} 
using EBIT as the dependent variable and find comparable results (see Specifications (5) to (8)).

\subsection{Robustness Checks}

Last, we ran a set of sensitivity checks. Due to space restrictions, many of the robustness checks are only sketched in the text whereas the detailed results are available from the authors upon request.

First, we hedge against the possibility that our parent dummy estimate picks up a firm age effect. Younger corporations are often perceived to be less profitable than more established firms since they e.g. still have to engage in upfront investments. As parent firms are commonly older than their subsidiaries, the observed profitability gap may simply reflect this age difference. Thus, we rerun our baseline specifications and additionally include the firm age as a control variable. The results are presented in Table 7 and indicate that the profitability gap is robust against controlling for firm age. ${ }^{12}$ The coefficient estimates for the parent dummy is almost unchanged in size compared to the specifications without the age control variable. Moreover, the coefficient estimate for the age variable exhibits the expected positive sign, suggesting that more established firms earn higher returns on their input factors. Since the information on the date of incorporation is not available for all firms in the database, the number of observations drops by around $20 \%$.

[Table 7 here]

In a second step, we furthermore investigate whether our results are unique to the international context or whether the profitability gap prevails on a domestic scale. To assess the profitability gap within national groups, we use a sample of domestic enterprises, i.e. parent firms and their domestic subsidiaries, drawn from the AMADEUS data base for the same countries and years as our baseline sample. ${ }^{13}$ The regressions

holding tax rate on dividends. As this sample restriction does neither qualitatively nor quantitatively change our findings, we are confident that withholding taxes are not a major driver of our results.

${ }^{12}$ The specifications presented in Table 7 use the logarithm of firm age as explanatory variable since the firm age distribution is considerably skewed. Alternatively, taking no logarithmic transformation of the age variable and additionally including the quadratic transformation yields the same estimations results. Then, the coefficient estimate for the age variable turns out to be positive while the coefficient estimate for the age-squared variable is significantly negative.

${ }^{13}$ The parents in this new sample are domestic ultimate owners of their subsidiaries, i.e. some of the 
include around 450, 000 observations from about 80, 000 affiliates. The results are presented in Table 8 and show qualitatively the same picture as our baseline regressions for MNEs whereas the estimated profitability gap is however - as expected - quantitatively smaller (roughly one third of the profitability gap in the baseline specifications). ${ }^{14}$

[Table 8 here]

Moreover, we hedge against potential reverse causality problems which may arise if highly profitable firms are more likely to be a multinational parent. This might be problematic, especially as in mergers \& acquisition the more profitable firm is perceived to commonly take over the less profitable one. To account for this possibility, we run a robustness check identifying corporate affiliates which were either acquired by a corporate group in the past or which took over a foreign subsidiary through an M\&A by using Bureau van Dijk's ZEPHYR database which contains M\&A back until 1997. Excluding these affiliates from the data does neither qualitatively nor quantitatively change our results. ${ }^{15}$

In further robustness checks, we reran our regressions including only subsidiaries that do not own any further subsidiaries themselves which slightly increased the quantitative coefficient estimates of the parent dummy. Moreover, we excluded holding companies from our baseline MNE-sample which likewise strengthened the profitability bias. Additionally, we repeated the regression analysis including affiliates with negative profits which leaves our qualitative results unaffected. Last, we split our baseline MNE-sample

parent firms may observe a foreign shareholder implying that they operate on an international scale. In a sensitivity check, we restricted the sample to purely national groups without any international ownership connections and found comparable results.

${ }^{14}$ Note, that the coefficient estimates for the parent dummy in the 'multinational' baseline and the 'domestic' sensitivity regression are statistically different at the $99 \%$ confidence level. Moreover, in the latter regressions the corruption index enters negatively suggesting a risk premium required by domestic corporations doing business (that mostly have no international location opportunity like MNEs) if corruption is high and property rights are less protected (represented by a low index).

${ }^{15}$ Note, however, that the data indeed indicates that in M\&A more profitable firms on average take over less profitable ones. Moreover, since there is some (weak) positive correlation between the parent dummy variable and the size of the input factors, we account for potential reverse causality between the profitability measure and the input factors by rerunning our equations and instrumenting for the input factor variables fixed assets (per sales) and cost of employees (per sales) and for the leverage ratio through lagged values of these variables. The regressions show neither a qualitative nor a quantitative change in our parent dummy effect and thus suggest no serious endogeneity problems with these firm variables. 
into ten industry groups (at the NACE 1-digit level) and found the profitability gap between parent firms and their foreign subsidiaries to be rather homogeneous across the industries.

\section{Implications}

Thus, our analysis finds robust evidence for a profitability bias in the location of valuable operations and projects in favor of the parent firm. Although the documented profitability gap between parents and subsidiaries has declined over the recent years, we still find it to be sizable. Our results have implications for several areas of research and policy making.

First, they imply that headquarters firms pay higher taxes on their corporate activity than subsidiaries, simply because headquarters activities are more profitable. To test this implication empirically, we use our baseline sample and regress an affiliate's unconsolidated tax payments on the parent dummy and a set of control variables (size controls, a full set of group fixed effects, country fixed effects, industry fixed effects and time-varying country characteristics). The results are depicted in Table 9. While the specifications presented in Columns (1) to (4) use the level a an affiliate's tax payments as the dependent variable, the specifications in Columns (5) to (8) are normalized on the affiliate's sales variable, and thus the regressand is tax payments per sales. The coefficient estimate for the parent dummy exhibits a positive sign and is statistically significant at the $1 \%$ level. Quantitatively, parent firms are found to observe by $61 \%$ higher tax payments on their corporate activity compared to their subsidiaries (cf. Column (8) of Table 9). ${ }^{16}$

[Table 9 here]

\footnotetext{
${ }^{16}$ There may be concerns that the gap in tax payments between headquarters and their subsidiaries is driven by residence based taxation in the MNE's home country which may enhance the MNE's tax bill at the headquarters location. As this argument refers to a relatively small number of European countries with residence based taxation according to a credit system (Bulgaria, Czech Republic, Estonia, Greece, Ireland, Poland, Romania, United Kingdom), we reran our regressions excluding all groups that are headquartered in a credit country and found our results qualitatively and quantitatively unchanged. The results are available from the authors upon request. Note furthermore that we observe the same qualitative results of the parent dummy on tax payments for our sample of parent firms and their domestic subsidiaries, however, to a lesser extend as also the profitability gab is smaller for this sample.
} 
Along the same lines, the documented profitability bias might well influence multinational profit shifting behavior in response to corporate tax rate differentials. A large literature shows that multinational firms engage in profit shifting activities from hightax to low-tax countries in order to reduce their corporate tax burden (see e.g. Clausing, 2003; Huizinga and Laeven, 2008). If MNEs are however reluctant to relocate profitable operations and profitable assets away from the headquarters firm then they might respond less to tax rate differentials between the headquarters and the corporate subsidiaries if the head office is located in a high-tax country. In the contrary, if the headquarters firm is located in a low-tax country and consequently profit shifting activities run from the subsidiaries toward the headquarters location, profit shifting is expected to be strongly responsive to tax rate differentials. A proper analysis of these aspects goes beyond the scope of this work and is referred to a companion paper (Dischinger and Riedel, 2009).

Additionally, several papers in the literature have suggested that the wages bargained for workers at a multinational affiliate are strongly dependent on the affiliate's profitability (see e.g. Budd, Konings, and Slaughter, 2005). In the context of our paper, this would suggest that workers at multinational headquarters firms earn higher wages than comparable workers at the subsidiary level. Our data is unfortunately not well suited to investigate this question as we do not observe information on the employees' skill level. Thus, although preliminary estimates show a positive correlation between the parent dummy and affiliate workers' wages, we cannot exclude that this correlation is driven by an unobservable variable bias. Thus, we have to delegate this question to future research.

\section{Conclusions}

This paper provides evidence that the location of profits within multinational enterprises is biased toward the headquarters firm. Using a large panel of European MNEs and conditioning on input factors employed, our most conservative estimates suggest that headquarters exhibit a $30 \%$ higher profitability than their foreign subsidiaries. In line with previous theoretical contributions, the paper discusses that this pattern might be driven by two effects: firstly, MNEs may prefer to keep their value-driving functions at the headquarters location as physical distance to foreign subsidiaries gives rise to agency problems; and secondly, MNEs may have advantages from operating in home markets as they commonly know local customs and consumer behavior better than foreign competitors. We present suggestive evidence which proposes a role for 
both mechanisms in driving the profitability gap.

However, our results also indicate some cracks in the notion and status of the parent company as profit center of the multinational group. Precisely, we find that the profitability gap between parents and their subsidiaries decreases over time. Quantitatively, the decrease is sizable, pointing to a decline of the gap by up to around $30 \%$ in seven years. This result is in line with the widespread perception of an increased fragmentation of the production process across international borders which today does not only comprise standard operating functions like manufacturing and sales but equally includes value-driving units like $R \& D$ and licensing departments (see Dischinger and Riedel, 2008). This especially applies as our results suggest that the closure of the profitability gap is related to the agency cost argument and not to the home market effect.

The results have various implications for public economic policy. Our analysis for example shows that headquarters firms pay higher taxes on their corporate activity than subsidiaries. Moreover, in a companion paper we find that MNEs are reluctant to shift profits and profitable assets away from corporate headquarters in response to tax rate differentials. Additionally, higher profitability rates at the multinational headquarters firms are expected to translate into a wage premium for the parent firm's workers. Consequently, our findings suggests that countries experience larger welfare gains from hosting a multinational parent firm than from hosting a multinational subsidiary. This implies that governments in general have a higher incentive to support and develop their multinational headquarters firms than to attract foreign subsidiaries. In this context, the profitability gap between headquarters and subsidiaries may also rationalize recent government actions to avoid the take-over of national firms by foreign companies and the associated attempt to create national champions. 


\section{Appendix}

\begin{tabular}{|l|c|c|c|}
\hline \multicolumn{4}{|c|}{ Table 1: Country Statistics } \\
\hline \hline Country & All Affiliates & Parent Firms & Subsidiaries \\
\hline Austria & 271 & 135 & 136 \\
Belgium & 2,092 & 1,123 & 969 \\
Bulgaria & 78 & 5 & 73 \\
Croatia & 186 & 57 & 129 \\
Czech Republic & 519 & 77 & 442 \\
Denmark & 1,724 & 828 & 896 \\
Estonia & 240 & 24 & 216 \\
Finland & 537 & 14 & 523 \\
France & 2,838 & 1,283 & 1,555 \\
Germany & 1,395 & 731 & 664 \\
Great Britain & 3,175 & 960 & 2,215 \\
Hungary & 34 & 9 & 25 \\
Ireland & 30 & 30 & 0 \\
Italy & 2,339 & 1,418 & 921 \\
Latvia & 10 & 0 & 10 \\
Luxembourg & 23 & 14 & 9 \\
Netherlands & 2,068 & 1,404 & 664 \\
Norway & 1,112 & 365 & 747 \\
Poland & 738 & 44 & 694 \\
Portugal & 273 & 82 & 191 \\
Romania & 512 & 12 & 500 \\
Serbia & 69 & 2 & 67 \\
Slovakia & 82 & 5 & 77 \\
Spain & 2,644 & 1,231 & 1,413 \\
Sweden & 2,226 & 1,392 & 834 \\
Switzerland & 138 & 138 & 0 \\
Ukraine & 40 & 2 & 38 \\
\hline Sum & 25,393 & 11,385 & 14,008 \\
\hline
\end{tabular}




\begin{tabular}{|c|c|c|c|c|c|}
\hline \multicolumn{6}{|c|}{ Table 2: Descriptive Statistics } \\
\hline Variable & Obs. & Mean & Median & Min. & Max. \\
\hline Dummy Parent Firm & 107,930 & .4912 & 0 & 0 & 1 \\
\hline Profit before Tax $(\mathrm{PBT})^{\star}$ & 107,930 & 18,623 & 884 & 1 & $1.67 \mathrm{e}+07$ \\
\hline Earnings before Interest \& Tax $(\mathrm{EBIT}) \star$ & 107,930 & 14,857 & 850 & 1 & $1.52 \mathrm{e}+07$ \\
\hline Gross Profit Margin (PBT per Sales) & 100,181 & 2.32 & .0585 & $1.73 \mathrm{e}-05$ & 26,393 \\
\hline EBIT Margin (EBIT per Sales) & 100,181 & .1024 & .0576 & $1.73 \mathrm{e}-05$ & 295 \\
\hline Sales $\star$ & 100,181 & 191,893 & 16,151 & 1 & $1.46 \mathrm{e}+08$ \\
\hline Fixed Assets $\star$ & 107,930 & 154,263 & 2,486 & 1 & $1.04 \mathrm{e}+08$ \\
\hline Cost of Employees & 107,930 & 26,530 & 2,183 & 1 & $2.26 \mathrm{e}+07$ \\
\hline Number of Employees & 107,930 & 565 & 44 & 1 & 99,837 \\
\hline Financial Leverage Ratio & 102,227 & .5937 & 6209 & 0 & 1 \\
\hline $\mathrm{GDP}^{\wedge}$ & 107,864 & 932.1 & 610.7 & 5.63 & 2,915 \\
\hline GDP per Capita 4 & 107,864 & 28,778 & 27,892 & 633 & 74,471 \\
\hline Corruption Index & 107,864 & 7.34 & 7.4 & 1.5 & 10 \\
\hline Statutory Corporate Tax Rate & 107,864 & .3251 & .3399 & .1 & .523 \\
\hline \multicolumn{6}{|l|}{ Parent firms only: } \\
\hline$\overline{\text { Profit before Tax }(\mathrm{PBT}) \star}$ & 53,011 & 32,967 & 1,683 & 1 & $1.67 \mathrm{e}+07$ \\
\hline Earnings before Interest \& Tax $(\mathrm{EBIT}) \star$ & 53,011 & 26,711 & 1,538 & 1 & $1.52 \mathrm{e}+07$ \\
\hline Gross Profit Margin (PBT per Sales) & 48,650 & 3.53 & .0639 & $1.73 \mathrm{e}-05$ & 26,393 \\
\hline EBIT Margin (EBIT per Sales) & 48,650 & .1214 & .0605 & $3.22 \mathrm{e}-05$ & 295 \\
\hline Fixed Assets $\star$ & 53,011 & 285,419 & 8,612 & 1 & $1.04 \mathrm{e}+08$ \\
\hline Cost of Employees & 53,011 & 46,423 & 3,921 & 1 & $2.26 \mathrm{e}+07$ \\
\hline \multicolumn{6}{|l|}{ Subsidiary firms only: } \\
\hline Profit before Tax $(\mathrm{PBT})^{\star}$ & 54,919 & 4,778 & 520 & 1 & $8.06 \mathrm{e}+06$ \\
\hline Earnings before Interest \& Tax $(\text { EBIT })^{\star}$ & 54,919 & 3,878 & 528 & 1 & $2.64 \mathrm{e}+06$ \\
\hline Gross Profit Margin (PBT per Sales) & 51,531 & 1.18 & .0543 & $2.71 \mathrm{e}-05$ & 23,304 \\
\hline EBIT Margin (EBIT per Sales) & 51,531 & .0852 & .0549 & $1.73 \mathrm{e}-05$ & 64.7 \\
\hline Fixed Assets $\star$ & 54,919 & 27,664 & 599 & 1 & $3.76 \mathrm{e}+07$ \\
\hline Cost of Employees & 54,919 & 7,328 & 1,391 & 1 & $6.33 \mathrm{e}+06$ \\
\hline
\end{tabular}

Notes:

‡ Unconsolidated values, in thousand US dollars, current prices.

• = (total liabilities / total assets).

- In billion US dollars, current prices, data from IMF WEO Database October 2008.

- In US dollars, current prices, data from IMF WEO Database October 2008.

- Corruption Perceptions Index (CPI) from Transparency International (TI), ranks from 0 (extreme level of corruption) to 10 (free of corruption). 


\begin{tabular}{|c|c|c|c|c|c|c|c|c|}
\hline \multicolumn{9}{|c|}{$\begin{array}{c}\text { Table 3: Baseline Estimation I - Higher Parent Profits } \\
\text { OLS Group-Fixed-Effects, Panel 1999-2006 }\end{array}$} \\
\hline Dependent Variable & \multicolumn{4}{|c|}{ Log (Profit before Tax) } & \multicolumn{4}{|c|}{ Log EBIT } \\
\hline Explanatory Variables: & (1) & (2) & (3) & (4) & (5) & (6) & (7) & (8) \\
\hline Parent Dummy & $\begin{array}{l}.877^{* * *} \\
(.044)\end{array}$ & $\begin{array}{l}.858^{* * *} \\
(.046)\end{array}$ & $\begin{array}{l}.697^{* * *} \\
(.046)\end{array}$ & $\begin{array}{c}.650^{* * *} \\
(.046)\end{array}$ & $\begin{array}{l}.547^{* * *} \\
(.043)\end{array}$ & $\begin{array}{l}.497^{* * *} \\
(.044)\end{array}$ & $\begin{array}{c}.398^{* * *} \\
(.045)\end{array}$ & $\begin{array}{l}.429^{* * *} \\
(.045)\end{array}$ \\
\hline Log (Fixed Assets) & $\begin{array}{l}.231^{* * *} \\
(.008)\end{array}$ & $\begin{array}{l}.227^{* * *} \\
(.008)\end{array}$ & $\begin{array}{l}.216^{* * *} \\
(.008)\end{array}$ & $\begin{array}{l}.214^{* * *} \\
(.008)\end{array}$ & $\begin{array}{l}.148^{* * *} \\
(.008)\end{array}$ & $\begin{array}{l}.141^{* * *} \\
(.008)\end{array}$ & $\begin{array}{c}.136^{* * *} \\
(.008)\end{array}$ & $\begin{array}{l}.137^{* * *} \\
(.007)\end{array}$ \\
\hline Log (Cost Employees) & $\begin{array}{c}.464^{* * *} \\
(.011)\end{array}$ & $\begin{array}{l}.454^{* * *} \\
(.012)\end{array}$ & $\begin{array}{c}.488^{* * *} \\
(.012)\end{array}$ & $\begin{array}{l}.505^{* * *} \\
(.012)\end{array}$ & $\begin{array}{l}.606^{* * *} \\
(.011)\end{array}$ & $\begin{array}{l}.167^{* * *} \\
(.012)\end{array}$ & $\begin{array}{c}.634^{* * *} \\
(.012)\end{array}$ & $\begin{array}{l}.633^{* * *} \\
(.012)\end{array}$ \\
\hline Leverage Ratio & & & $\begin{array}{c}-1.26^{* * *} \\
(.043)\end{array}$ & $\begin{array}{c}-1.26^{* * *} \\
(.043)\end{array}$ & & & $\begin{array}{c}-.720^{* * *} \\
(.040)\end{array}$ & $\begin{array}{c}-.726^{* * *} \\
(.039)\end{array}$ \\
\hline Log GDP & & $\begin{array}{l}-.238 \\
(.148)\end{array}$ & $\begin{array}{l}-.222 \\
(.143)\end{array}$ & $\begin{array}{l}-.172 \\
(.184)\end{array}$ & & $\begin{array}{c}-.209^{* * *} \\
(.066)\end{array}$ & $\begin{array}{c}-.199^{* * *} \\
(.061)\end{array}$ & $\begin{array}{c}-.189^{* *} \\
(.079)\end{array}$ \\
\hline Log (GDP p.Capita) & & $\begin{array}{l}.609^{* * *} \\
(.169)\end{array}$ & $\begin{array}{l}.414^{* * *} \\
(.165)\end{array}$ & $\begin{array}{l}.339^{*} \\
(.201)\end{array}$ & & $\begin{array}{l}.315^{* * *} \\
(.101)\end{array}$ & $\begin{array}{l}.212^{* *} \\
(.098)\end{array}$ & $\begin{array}{l}.203^{*} \\
(.110)\end{array}$ \\
\hline Log Corruption & & $\begin{array}{l}.231^{* * *} \\
(.079)\end{array}$ & $\begin{array}{c}.303^{* * *} \\
(.079)\end{array}$ & $\begin{array}{l}.296^{* * *} \\
(.079)\end{array}$ & & $\begin{array}{l}.138^{* *} \\
(.068)\end{array}$ & $\begin{array}{r}.177^{* * *} \\
(.069)\end{array}$ & $\begin{array}{l}.166^{* *} \\
(.069)\end{array}$ \\
\hline Statutory Tax Rate & & $\begin{array}{c}-.962^{* * *} \\
(.239)\end{array}$ & $\begin{array}{c}-.754^{* * *} \\
(.235)\end{array}$ & $\begin{array}{c}-.784^{* * *} \\
(.236)\end{array}$ & & $\begin{array}{c}-.609^{* * *} \\
(.215)\end{array}$ & $\begin{array}{r}-.407^{*} \\
(.220)\end{array}$ & $\begin{array}{r}-.418^{*} \\
(.220)\end{array}$ \\
\hline Year Dummies & $\sqrt{ }$ & $\sqrt{ }$ & $\sqrt{ }$ & $\sqrt{ }$ & $\sqrt{ }$ & $\sqrt{ }$ & $\sqrt{ }$ & $\sqrt{ }$ \\
\hline Country Dummies & & $\sqrt{ }$ & $\sqrt{ }$ & $\sqrt{ }$ & & $\sqrt{ }$ & $\sqrt{ }$ & $\sqrt{ }$ \\
\hline Industry Dummies & & & & $\sqrt{ }$ & & & & $\sqrt{ }$ \\
\hline \# Observations & 107,930 & 107,864 & 102,227 & 101,828 & 107,106 & 107,046 & 100,973 & 100,567 \\
\hline \# MNE-Groups & 18,531 & 18,531 & 18,007 & 17,923 & 18,067 & 18,066 & 17,514 & 17,433 \\
\hline Adjusted $R^{2}$ & .7928 & .7940 & .8033 & .8041 & .8117 & .8140 & .8192 & .8204 \\
\hline
\end{tabular}

Notes:

Heteroscedasticity robust standard errors adjusted for group clusters in parentheses.

${ }^{*},{ }^{* *},{ }^{* * *}$ indicates significance at the $10 \%, 5 \%, 1 \%$ level. The observational units are profit-making multinational parent firms and multinational subsidiaries. A group-fixed-effect is set for belonging to a MNE-group. Parent Dummy is a dummy variable set to 1 if an observational unit is a parent firm and set to 0 if it is a subsidiary. Log (Cost Employees) is the natural logarithm ( $\mathrm{Log})$ of the cost of employees. 56 industry dummies (NACE Rev.12-digit level) and 27 country dummies are included where indicated. Adjusted $R^{2}$ values are calculated from a dummy variables regression equivalent to the fixed-effects model. 


\begin{tabular}{|c|c|c|c|c|c|c|c|c|}
\hline \multicolumn{9}{|c|}{$\begin{array}{c}\text { Table 4: Baseline Estimation II - Higher Parent Profitability } \\
\text { OLS Group-Fixed-Effects, Panel 1999-2006 }\end{array}$} \\
\hline \multirow{2}{*}{$\begin{array}{l}\text { Dependent Variable } \\
\text { Explanatory Variables: }\end{array}$} & \multicolumn{4}{|c|}{ Log (Profit b. Tax per Sales) } & \multicolumn{4}{|c|}{ Log (EBIT per Sales) } \\
\hline & (1) & (2) & (3) & (4) & (5) & (6) & (7) & (8) \\
\hline Parent Dummy & $\begin{array}{l}.930^{* * *} \\
(.046)\end{array}$ & $\begin{array}{c}.927^{* * *} \\
(.048)\end{array}$ & $\begin{array}{l}.746^{* * *} \\
(.048)\end{array}$ & $\begin{array}{l}.648^{* * *} \\
(.047)\end{array}$ & $\begin{array}{l}.471^{* * *} \\
(.038)\end{array}$ & $\begin{array}{l}.443^{* * *} \\
(.039)\end{array}$ & $\begin{array}{l}.299^{* * *} \\
(.039)\end{array}$ & $\begin{array}{l}.291^{* * *} \\
(.039)\end{array}$ \\
\hline $\begin{array}{l}\log (\text { Fixed Assets } \\
\text { per Sales) }\end{array}$ & $\begin{array}{l}.444^{* * *} \\
(.015)\end{array}$ & $\begin{array}{l}.454^{* * *} \\
(.015)\end{array}$ & $\begin{array}{l}.407^{* * *} \\
(.015)\end{array}$ & $\begin{array}{l}.369^{* * *} \\
(.014)\end{array}$ & $\begin{array}{l}.193^{* * *} \\
(.010)\end{array}$ & $\begin{array}{l}.183^{* * *} \\
(.010)\end{array}$ & $\begin{array}{l}.145^{* * *} \\
(.010)\end{array}$ & $\begin{array}{r}.137^{* * *} \\
(.010)\end{array}$ \\
\hline $\begin{array}{r}\log (\text { Cost Employees } \\
\text { per Sales })\end{array}$ & $\begin{array}{l}.043^{* * *} \\
(.017)\end{array}$ & $\begin{array}{l}.032^{*} \\
(.018)\end{array}$ & $\begin{array}{l}.014 \\
(.018)\end{array}$ & $\begin{array}{l}.016 \\
(.018)\end{array}$ & $\begin{array}{c}-.054^{* * *} \\
(.018)\end{array}$ & $\begin{array}{c}-.039^{* *} \\
(.019)\end{array}$ & $\begin{array}{c}-.061^{* * *} \\
(.019)\end{array}$ & $\begin{array}{c}-.068^{* * *} \\
(.019)\end{array}$ \\
\hline Log (Fixed Assets) & $\begin{array}{c}-.243^{* * *} \\
(.009)\end{array}$ & $\begin{array}{c}-.255^{* * *} \\
(.010)\end{array}$ & $\begin{array}{c}-.222^{* * *} \\
(.010)\end{array}$ & $\begin{array}{c}-.200^{* * *} \\
(.010)\end{array}$ & $\begin{array}{c}-.120^{* * *} \\
(.007)\end{array}$ & $\begin{array}{c}-.112^{* * *} \\
(.008)\end{array}$ & $\begin{array}{c}-.087^{* * *} \\
(.008)\end{array}$ & $\begin{array}{c}-.089^{* * *} \\
(.008)\end{array}$ \\
\hline Leverage Ratio & & & $\begin{array}{c}-1.57^{* * *} \\
(.044)\end{array}$ & $\begin{array}{c}-1.58^{* * *} \\
(.043)\end{array}$ & & & $\begin{array}{c}-1.14^{* * *} \\
(.035)\end{array}$ & $\begin{array}{c}-1.13^{* * *} \\
(.035)\end{array}$ \\
\hline Log GDP & & $\begin{array}{l}-.217 \\
(.148)\end{array}$ & $\begin{array}{l}-.193 \\
(.143)\end{array}$ & $\begin{array}{l}-.141 \\
(.183)\end{array}$ & & $\begin{array}{c}-.182^{* * *} \\
(.064)\end{array}$ & $\begin{array}{c}-.165^{* * *} \\
(.061)\end{array}$ & $\begin{array}{c}-.148^{* *} \\
(.071)\end{array}$ \\
\hline Log (GDP p.Capita) & & $\begin{array}{l}.568^{* * *} \\
(.167)\end{array}$ & $\begin{array}{l}.322^{* *} \\
(.162)\end{array}$ & $\begin{array}{c}.231 \\
(.198)\end{array}$ & & $\begin{array}{l}.169^{*} \\
(.093)\end{array}$ & $\begin{array}{l}-.012 \\
(.090)\end{array}$ & $\begin{array}{l}-.025 \\
(.097)\end{array}$ \\
\hline Log Corruption & & $\begin{array}{l}.170^{* *} \\
(.079)\end{array}$ & $\begin{array}{l}.274^{* * *} \\
(.077)\end{array}$ & $\begin{array}{l}.275^{* * *} \\
(.077)\end{array}$ & & $\begin{array}{l}.105^{*} \\
(.065)\end{array}$ & $\begin{array}{l}.190^{* * *} \\
(.064)\end{array}$ & $\begin{array}{l}.186^{* * *} \\
(.064)\end{array}$ \\
\hline Statutory Tax Rate & & $\begin{array}{c}-.652^{* * *} \\
(.231)\end{array}$ & $\begin{array}{l}-.351 \\
(.226)\end{array}$ & $\begin{array}{l}-.362 \\
(.227)\end{array}$ & & $\begin{array}{l}-.311 \\
(.197)\end{array}$ & $\begin{array}{l}.033 \\
(.199)\end{array}$ & $\begin{array}{l}.016 \\
(.200)\end{array}$ \\
\hline Year Dummies & $\sqrt{ }$ & $\sqrt{ }$ & $\sqrt{ }$ & $\sqrt{ }$ & $\sqrt{ }$ & $\sqrt{ }$ & $\sqrt{ }$ & $\sqrt{ }$ \\
\hline Country Dummies & & $\sqrt{ }$ & $\sqrt{ }$ & $\sqrt{ }$ & & $\sqrt{ }$ & $\sqrt{ }$ & $\sqrt{ }$ \\
\hline Industry Dummies & & & & $\sqrt{ }$ & & & & $\sqrt{ }$ \\
\hline \# Observations & 100,181 & 100,117 & 94,893 & 94,525 & 99,846 & 99,786 & 94,143 & 93,766 \\
\hline \# MNE-Groups & 17,191 & 17,191 & 16,702 & 16,624 & 16,846 & 16,845 & 16,337 & 16,261 \\
\hline Adjusted $R^{2}$ & .5987 & .6003 & .6303 & .6340 & .4662 & .4698 & .4976 & .5010 \\
\hline
\end{tabular}

Notes:

Heteroscedasticity robust standard errors adjusted for group clusters in parentheses.

${ }^{*},{ }^{* *},{ }^{* * *}$ indicates significance at the $10 \%, 5 \%, 1 \%$ level. The observational units are profit-making multinational parent firms and multinational subsidiaries. A group-fixed-effect is set for belonging to a MNE-group. Parent Dummy is a dummy variable set to 1 if an observational unit is a parent firm and set to 0 if it is a subsidiary. Log (Cost Employees per Sales) is the natural logarithm (Log) of the cost of employees per sales. 56 industry dummies (NACE Rev.1 2-digit level) and 27 country dummies are included where indicated. Adjusted $R^{2}$ values are calculated from a dummy variables regression equivalent to the fixed-effects model 
Table 5: Extension - Development over Time

OLS Group-Fixed-Effects, Panel 1999-2006

\begin{tabular}{|c|c|c|c|c|c|c|c|c|}
\hline Dependent Variable & \multicolumn{2}{|c|}{ Log PBT } & \multicolumn{2}{|c|}{ Log EBIT } & \multicolumn{2}{|c|}{ Log(PBT p.Sales) } & \multicolumn{2}{|c|}{ Log(EBIT p.Sales) } \\
\hline Explanatory Variables: & (1) & (2) & (3) & (4) & (5) & (6) & (7) & (8) \\
\hline Parent Dummy & $\begin{array}{l}.968^{* * *} \\
(.047)\end{array}$ & $\begin{array}{l}.714^{* * *} \\
(.049)\end{array}$ & $\begin{array}{l}.635^{* * *} \\
(.045)\end{array}$ & $\begin{array}{l}.503^{* * *} \\
(.047)\end{array}$ & $\begin{array}{l}1.02^{* * *} \\
(.049)\end{array}$ & $\begin{array}{l}.702^{* * *} \\
(.049)\end{array}$ & $\begin{array}{l}.560^{* * *} \\
(.040)\end{array}$ & $\begin{array}{l}.360^{* * *} \\
(.041)\end{array}$ \\
\hline Parent $\times$ Time & $\begin{array}{c}-.024^{* * *} \\
(.004)\end{array}$ & $\begin{array}{c}-.017^{* * *} \\
(.004)\end{array}$ & $\begin{array}{c}-.024^{* * *} \\
(.004)\end{array}$ & $\begin{array}{c}-.020^{* * *} \\
(.004)\end{array}$ & $\begin{array}{c}-.025^{* * *} \\
(.004)\end{array}$ & $\begin{array}{c}-.015^{* * *} \\
(.004)\end{array}$ & $\begin{array}{c}-.024^{* * * *} \\
(.003)\end{array}$ & $\begin{array}{c}-.019^{* * *} \\
(.003)\end{array}$ \\
\hline Time & $\begin{array}{l}.062^{* * *} \\
(.003)\end{array}$ & $\begin{array}{l}.033^{* * *} \\
(.007)\end{array}$ & $\begin{array}{l}.036^{* * *} \\
(.003)\end{array}$ & $\begin{array}{l}.028^{* * *} \\
(.006)\end{array}$ & $\begin{array}{l}.059^{* * *} \\
(.003)\end{array}$ & $\begin{array}{l}.031^{* * *} \\
(.007)\end{array}$ & $\begin{array}{l}.026^{* * *} \\
(.003)\end{array}$ & $\begin{array}{l}.027^{* * *} \\
(.006)\end{array}$ \\
\hline Log (Fixed Assets) & $\begin{array}{l}.233^{* * *} \\
(.008)\end{array}$ & $\begin{array}{l}.216^{* * *} \\
(.008)\end{array}$ & $\begin{array}{l}.151^{* * *} \\
(.008)\end{array}$ & $\begin{array}{l}.140^{* * *} \\
(.008)\end{array}$ & $\begin{array}{c}-.243^{* * *} \\
(.009)\end{array}$ & $\begin{array}{c}-.199^{* * *} \\
(.010)\end{array}$ & $\begin{array}{c}-.119^{* * *} \\
(.007)\end{array}$ & $\begin{array}{c}-.088^{* * *} \\
(.008)\end{array}$ \\
\hline Log (Cost Employees) & $\begin{array}{l}.463^{* * *} \\
(.011)\end{array}$ & $\begin{array}{l}.504^{* * *} \\
(.012)\end{array}$ & $\begin{array}{l}.604^{* * *} \\
(.011)\end{array}$ & $\begin{array}{l}.632^{* * *} \\
(.012)\end{array}$ & & & & \\
\hline $\begin{array}{l}\text { Log (Fixed Assets } \\
\text { per Sales) }\end{array}$ & & & & & $\begin{array}{l}.446^{* * *} \\
(.015)\end{array}$ & $\begin{array}{l}.370^{* * *} \\
(.014)\end{array}$ & $\begin{array}{l}.196^{* * *} \\
(.010)\end{array}$ & $\begin{array}{l}.138^{* * *} \\
(.010)\end{array}$ \\
\hline $\begin{array}{r}\text { Log (Cost Employees } \\
\text { per Sales) }\end{array}$ & & & & & $\begin{array}{l}.041^{* *} \\
(.017)\end{array}$ & $\begin{array}{l}.015 \\
(.018)\end{array}$ & $\begin{array}{c}-.056^{* * *} \\
(.018)\end{array}$ & $\begin{array}{c}-.069^{* * *} \\
(.019)\end{array}$ \\
\hline Leverage Ratio & & $\begin{array}{c}-1.26^{* * *} \\
(.042)\end{array}$ & & $\begin{array}{c}-.722^{* * *} \\
(.039)\end{array}$ & & $\begin{array}{c}-1.58^{* * *} \\
(.043)\end{array}$ & & $\begin{array}{c}-1.12^{* * *} \\
(.035)\end{array}$ \\
\hline Log GDP & & $\begin{array}{l}-.163 \\
(.181)\end{array}$ & & $\begin{array}{c}-.171^{* *} \\
(.073)\end{array}$ & & $\begin{array}{l}-.134 \\
(.181)\end{array}$ & & $\begin{array}{c}-.133^{* *} \\
(.066)\end{array}$ \\
\hline Log (GDP p.Capita) & & $\begin{array}{l}.263 \\
(.199)\end{array}$ & & $\begin{array}{l}.106 \\
(.107)\end{array}$ & & $\begin{array}{l}.167 \\
(.198)\end{array}$ & & $\begin{array}{l}-.113 \\
(.095)\end{array}$ \\
\hline Log Corruption & & $\begin{array}{l}.296^{* * *} \\
(.079)\end{array}$ & & $\begin{array}{l}.166^{* *} \\
(.069)\end{array}$ & & $\begin{array}{l}.273^{* * *} \\
(.077)\end{array}$ & & $\begin{array}{l}.183^{* * *} \\
(.064)\end{array}$ \\
\hline Statutory Tax Rate & & $\begin{array}{c}-.781^{* * * *} \\
(.236)\end{array}$ & & $\begin{array}{r}-.414^{*} \\
(.220)\end{array}$ & & $\begin{array}{l}-.350 \\
(.227)\end{array}$ & & $\begin{array}{c}.033 \\
(.200)\end{array}$ \\
\hline Year Dummies & $\sqrt{ }$ & $\sqrt{ }$ & $\sqrt{ }$ & $\sqrt{ }$ & $\sqrt{ }$ & $\sqrt{ }$ & $\sqrt{ }$ & $\sqrt{ }$ \\
\hline Country Dummies & & $\sqrt{ }$ & & $\sqrt{ }$ & & $\sqrt{ }$ & & $\sqrt{ }$ \\
\hline Industry Dummies & & $\sqrt{ }$ & & $\sqrt{ }$ & & $\sqrt{ }$ & & $\sqrt{ }$ \\
\hline \# Observations & 107,930 & 101,828 & 107,106 & 100,567 & 100,181 & 94,525 & 99,846 & 93,766 \\
\hline \# MNE-Groups & 18,531 & 17,923 & 18,067 & 17,433 & 17,191 & 16,624 & 16,846 & 16,261 \\
\hline Adjusted $R^{2}$ & .7930 & .8042 & .8119 & .8205 & .5990 & .6341 & .4668 & .5013 \\
\hline
\end{tabular}

Notes:

Heteroscedasticity robust standard errors adjusted for group clusters in parentheses.

$*, * *, * * *$ indicates significance at the $10 \%, 5 \%, 1 \%$ level. The observational units are profit-making multinational parent firms and multinational subsidiaries. A group-fixed-effect is set for belonging to a MNE-group. The abbreviation PBT stands for Profit before Tax. Parent Dummy is a dummy variable set to 1 if an observational unit is a parent firm and set to 0 if it is a subsidiary. Time is set to 0 for the year 1999, 1 for 2000, 2 for $2001, \ldots$, and 7 for 2006 , with a mean of 3.5. Parent $\times$ Time is the interaction term between Parent Dummy and Time. Log (Cost Employees per Sales) is the natural logarithm ( $\mathrm{Log}$ ) of the cost of employees per sales. 56 industry dummies (NACE Rev.1 2-digit level) and 27 country dummies are included where indicated. Adjusted $R^{2}$ values are calculated from a dummy variables regression equivalent to the fixed-effects model. 


\begin{tabular}{|c|c|c|c|c|c|c|c|c|}
\hline \multicolumn{9}{|c|}{$\begin{array}{c}\text { Table 6: Extension - Vertical \& Horizontal FDI } \\
\text { OLS Group-Fixed-Effects, Panel 1999-2006 }\end{array}$} \\
\hline Dependent Variable & \multicolumn{2}{|c|}{ Log PBT } & \multicolumn{2}{|c|}{ Log PBT } & \multicolumn{2}{|c|}{ Log EBIT } & \multicolumn{2}{|c|}{ Log EBIT } \\
\hline Explanatory Variables: & $(1)$ & (2) & (3) & (4) & $(5)$ & $(6)$ & $(7)$ & $(8)$ \\
\hline Parent Dummy & $\begin{array}{l}.917^{\text {**** }} \\
(.092)\end{array}$ & $\begin{array}{l}.608^{* * *} \\
(.060)\end{array}$ & $\begin{array}{l}.917^{* * *} \\
(.119)\end{array}$ & $\begin{array}{l}.677^{* * *} \\
(.066)\end{array}$ & $\begin{array}{l}.630^{* * *} \\
(.097)\end{array}$ & $\begin{array}{l}.368^{* * *} \\
(.059)\end{array}$ & $\begin{array}{l}.686^{* * *} \\
(.118)\end{array}$ & $\begin{array}{l}.437^{* * *} \\
(.064)\end{array}$ \\
\hline Parent $\times$ Time & & & $\begin{array}{l}-.000 \\
(.016)\end{array}$ & $\begin{array}{c}-.018^{* * *} \\
(.007)\end{array}$ & & & $\begin{array}{l}-.014 \\
(.016)\end{array}$ & $\begin{array}{c}-.018^{* * *} \\
(.006)\end{array}$ \\
\hline Time & & & $\begin{array}{l}.038^{* * *} \\
(.020)\end{array}$ & $\begin{array}{l}.024^{* * *} \\
(.012)\end{array}$ & & & $\begin{array}{l}.045^{* *} \\
(.019)\end{array}$ & $\begin{array}{c}.025^{* * *} \\
(.011)\end{array}$ \\
\hline Log (Fixed Assets) & $\begin{array}{l}.164^{* * * *} \\
(.012)\end{array}$ & $\begin{array}{l}.240^{* * *} \\
(.011)\end{array}$ & $\begin{array}{l}.164^{* * *} \\
(.012)\end{array}$ & $\begin{array}{l}.241^{* * *} \\
(.011)\end{array}$ & $\begin{array}{c}.130^{* * *} \\
(.012)\end{array}$ & $\begin{array}{l}.158^{* * *} \\
(.010)\end{array}$ & $\begin{array}{l}.131^{* * *} \\
(.012)\end{array}$ & $\begin{array}{l}.160^{* * *} \\
(.010)\end{array}$ \\
\hline Log (Cost Employees) & $\begin{array}{l}.466^{* * *} \\
(.018)\end{array}$ & $\begin{array}{l}.472^{* * *} \\
(.016)\end{array}$ & $\begin{array}{l}.466^{* * *} \\
(.018)\end{array}$ & $\begin{array}{l}.471^{* * *} \\
(.016)\end{array}$ & $\begin{array}{l}.560^{* * *} \\
(.020)\end{array}$ & $\begin{array}{l}.611^{* * *} \\
(.017)\end{array}$ & $\begin{array}{l}.560^{* * *} \\
(.020)\end{array}$ & $\begin{array}{l}.610^{* * *} \\
(.017)\end{array}$ \\
\hline Leverage Ratio & $\begin{array}{c}-1.172^{* * *} \\
(.061)\end{array}$ & $\begin{array}{c}-1.311^{* * *} \\
(.062)\end{array}$ & $\begin{array}{c}-1.172^{* * *} \\
(.061)\end{array}$ & $\begin{array}{c}-1.311^{* * *} \\
(.062)\end{array}$ & $\begin{array}{c}-.607^{* * *} \\
(.058)\end{array}$ & $\begin{array}{c}-.656^{* * *} \\
(.054)\end{array}$ & $\begin{array}{c}-.607^{* * *} \\
(.058)\end{array}$ & $\begin{array}{c}-.655^{* * *} \\
(.054)\end{array}$ \\
\hline Log GDP & $\begin{array}{l}-.238^{*} \\
(.137)\end{array}$ & $\begin{array}{l}-.251^{*} \\
(.137)\end{array}$ & $\begin{array}{l}-.238^{*} \\
(.137)\end{array}$ & $\begin{array}{l}-.244^{*} \\
(.136)\end{array}$ & $\begin{array}{c}-.108^{* *} \\
(.052)\end{array}$ & $\begin{array}{c}-.157^{* *} \\
(.066)\end{array}$ & $\begin{array}{c}-.106^{* *} \\
(.052)\end{array}$ & $\begin{array}{c}-.148^{* *} \\
(.063)\end{array}$ \\
\hline Log (GDP p.Capita) & $\begin{array}{l}.166 \\
(.213)\end{array}$ & $\begin{array}{l}.514^{* * *} \\
(.196)\end{array}$ & $\begin{array}{l}.166 \\
(.214)\end{array}$ & $\begin{array}{l}.453^{* *} \\
(.195)\end{array}$ & $\begin{array}{l}-.125 \\
(.155)\end{array}$ & $\begin{array}{l}.161 \\
(.140)\end{array}$ & $\begin{array}{l}-.142 \\
(.156)\end{array}$ & $\begin{array}{l}.094 \\
(.138)\end{array}$ \\
\hline Log Corruption & $\begin{array}{l}.431^{* * *} \\
(.112)\end{array}$ & $\begin{array}{l}.399^{* * *} \\
(.102)\end{array}$ & $\begin{array}{l}.431^{\text {**** }} \\
(.112)\end{array}$ & $\begin{array}{l}.387^{* *} \\
(.102)\end{array}$ & $\begin{array}{l}.260^{* * *} \\
(.098)\end{array}$ & $\begin{array}{l}.226^{* * *} \\
(.087)\end{array}$ & $\begin{array}{l}.260^{* * * *} \\
(.098)\end{array}$ & $\begin{array}{l}.215^{* * *} \\
(.088)\end{array}$ \\
\hline Statutory Tax Rate & $\begin{array}{l}-.425 \\
(.338)\end{array}$ & $\begin{array}{c}-.800^{* * *} \\
(.318)\end{array}$ & $\begin{array}{l}-.425 \\
(.338)\end{array}$ & $\begin{array}{c}-.767^{* *} \\
(.317)\end{array}$ & $\begin{array}{l}-.000 \\
(.326)\end{array}$ & $\begin{array}{l}-.541^{*} \\
(.299)\end{array}$ & $\begin{array}{c}.006 \\
(.327)\end{array}$ & $\begin{array}{l}-.505^{*} \\
(.298)\end{array}$ \\
\hline Investment Type & $\mathrm{H}$ & $\mathrm{V}$ & $\mathrm{H}$ & $\mathrm{V}$ & $\mathrm{H}$ & $\mathrm{V}$ & $\mathrm{H}$ & $\mathrm{V}$ \\
\hline Year Dummies & $\sqrt{ }$ & $\sqrt{ }$ & $\sqrt{ }$ & $\sqrt{ }$ & $\sqrt{ }$ & $\sqrt{ }$ & $\sqrt{ }$ & $\sqrt{ }$ \\
\hline Country Dummies & $\sqrt{ }$ & $\sqrt{ }$ & $\sqrt{ }$ & $\sqrt{ }$ & $\sqrt{ }$ & $\sqrt{ }$ & $\sqrt{ }$ & $\sqrt{ }$ \\
\hline Industry Dummies & $\sqrt{ }$ & $\sqrt{ }$ & $\sqrt{ }$ & $\sqrt{ }$ & $\sqrt{ }$ & $\sqrt{ }$ & $\sqrt{ }$ & $\sqrt{ }$ \\
\hline \# Observations & 53,071 & 62,441 & 53,071 & 62,441 & 51,437 & 60,854 & 51,437 & 60,854 \\
\hline \# MNE-Groups & 11,187 & 17,923 & 11,187 & 17,923 & 10,652 & 10,854 & 10,652 & 10,854 \\
\hline Adjusted $R^{2}$ & .6037 & .6416 & .6037 & 0.6419 & .6637 & .6762 & .6644 & .6766 \\
\hline
\end{tabular}

Notes:

Heteroscedasticity robust standard errors adjusted for group clusters in parentheses.

${ }^{*},{ }^{* *},{ }^{* * *}$ indicates significance at the $10 \%, 5 \%, 1 \%$ level. The observational units are profit-making multinational parent firms and multinational subsidiaries. A group-fixed-effect is set for belonging to a MNE-group. The abbreviation PBT stands for Profit before Tax. Parent Dummy is a dummy variable set to 1 if an observational unit is a parent firm and set to 0 if it is a subsidiary. Time is set to 0 for the year 1999,1 for 2000,2 for $2001, \ldots$, and 7 for 2006 , with a mean of 3.5. Parent $\times$ Time is the interaction term between Parent Dummy and Time. Log (Cost Employees per Sales) is the natural logarithm (Log) of the cost of employees per sales. 56 industry dummies (NACE Rev.1 2-digit level) and 27 country dummies are included in all regressions. Moreover, the investment type " $\mathrm{H}$ " indicates horizontal FDI, i.e. the corresponding regressions in Column (1), (3), (5) and (7) include only subsidiaries for which the subsidiary observes the same four-digit NACE code industry as the parent firm. Analogously, the investment type "V" indicates vertical FDI, i.e. the corresponding regressions in Column (2), (4), (6) and (8) include only subsidiaries for which the subsidiary operates in a different four-digit NACE code industry than the parent firm. Adjusted $R^{2}$ values are calculated from a dummy variables regression equivalent to the fixed-effects model. 


\begin{tabular}{|c|c|c|c|c|c|c|c|c|}
\hline \multicolumn{9}{|c|}{$\begin{array}{c}\text { Table 7: Robustness Check - Control for Firm Age } \\
\text { OLS Group-Fixed-Effects, Panel 1999-2006 }\end{array}$} \\
\hline Dependent Variable & \multicolumn{2}{|c|}{ Log PBT } & \multicolumn{2}{|c|}{ 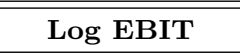 } & \multicolumn{2}{|c|}{ Log(PBT p.Sales) } & \multicolumn{2}{|c|}{ Log(EBIT p.Sales) } \\
\hline Explanatory Variables: & $(1)$ & (2) & (3) & (4) & $(5)$ & $(6)$ & $(7)$ & $(8)$ \\
\hline Parent Dummy & $\begin{array}{l}.923^{* * *} \\
(.058)\end{array}$ & $\begin{array}{l}.729^{* * *} \\
(.061)\end{array}$ & $\begin{array}{l}.560^{* * * *} \\
(.058)\end{array}$ & $\begin{array}{l}.467^{* * *} \\
(.060)\end{array}$ & $\begin{array}{l}.963^{* * *} \\
(.063)\end{array}$ & $\begin{array}{l}.740^{* * *} \\
(.062)\end{array}$ & $\begin{array}{l}.446^{* * *} \\
(.055)\end{array}$ & $\begin{array}{l}.295^{* * *} \\
(.054)\end{array}$ \\
\hline Log Age & $\begin{array}{l}.117^{* * *} \\
(.020)\end{array}$ & $\begin{array}{c}.067^{* * *} \\
(.021)\end{array}$ & $\begin{array}{l}.059^{* * *} \\
(.019)\end{array}$ & $\begin{array}{l}.046^{* *} \\
(.020)\end{array}$ & $\begin{array}{l}.097^{* * *} \\
(.022)\end{array}$ & $\begin{array}{l}.045^{* *} \\
(.021)\end{array}$ & $\begin{array}{l}.025 \\
(.016)\end{array}$ & $\begin{array}{l}.012 \\
(.016)\end{array}$ \\
\hline Log (Fixed Assets) & $\begin{array}{l}.214^{* * *} \\
(.011)\end{array}$ & $\begin{array}{l}.196^{* * *} \\
(.010)\end{array}$ & $\begin{array}{l}.140^{* * * *} \\
(.010)\end{array}$ & $\begin{array}{l}.130^{* * *} \\
(.009)\end{array}$ & $\begin{array}{c}-.286^{* * *} \\
(.013)\end{array}$ & $\begin{array}{c}-.235^{* * *} \\
(.014)\end{array}$ & $\begin{array}{c}-.119^{* * *} \\
(.011)\end{array}$ & $\begin{array}{c}-.087^{* * *} \\
(.011)\end{array}$ \\
\hline Log (Cost Employees) & $\begin{array}{l}.427^{* * *} \\
(.015)\end{array}$ & $\begin{array}{l}.478^{* * *} \\
(.017)\end{array}$ & $\begin{array}{l}.577^{* * *} \\
(.015)\end{array}$ & $\begin{array}{l}.607^{* * *} \\
(.016)\end{array}$ & & & & \\
\hline $\begin{array}{l}\text { Log (Fixed Assets } \\
\text { per Sales) }\end{array}$ & & & & & $\begin{array}{l}.471^{* * *} \\
(.019)\end{array}$ & $\begin{array}{l}.392^{* * *} \\
(.019)\end{array}$ & $\begin{array}{l}.172^{* * *} \\
(.013)\end{array}$ & $\begin{array}{l}.121^{* * *} \\
(.013)\end{array}$ \\
\hline $\begin{array}{r}\text { Log (Cost Employees } \\
\text { per Sales })\end{array}$ & & & & & $\begin{array}{l}.017 \\
(.020)\end{array}$ & $\begin{array}{l}.008 \\
(.021)\end{array}$ & $\begin{array}{c}-.116^{* * *} \\
(.019)\end{array}$ & $\begin{array}{c}-.115^{* * *} \\
(.020)\end{array}$ \\
\hline Leverage Ratio & & $\begin{array}{c}-1.22^{* * *} \\
(.053)\end{array}$ & & $\begin{array}{c}-.642^{* * *} \\
(.048)\end{array}$ & & $\begin{array}{c}-1.51^{* * *} \\
(.054)\end{array}$ & & $\begin{array}{c}-1.01^{* * *} \\
(.042)\end{array}$ \\
\hline Log GDP & & $\begin{array}{l}-.130 \\
(.170)\end{array}$ & & $\begin{array}{c}-.135^{* *} \\
(.060)\end{array}$ & & $\begin{array}{l}-.109 \\
(.176)\end{array}$ & & $\begin{array}{l}-.116^{*} \\
(.062)\end{array}$ \\
\hline Log (GDP p.Capita) & & $\begin{array}{l}.201 \\
(.206)\end{array}$ & & $\begin{array}{l}.006 \\
(.116)\end{array}$ & & $\begin{array}{l}.206 \\
(.208)\end{array}$ & & $\begin{array}{l}-.079 \\
(.106)\end{array}$ \\
\hline Log Corruption & & $\begin{array}{l}.312^{* * *} \\
(.093)\end{array}$ & & $\begin{array}{l}.199^{* *} \\
(.082)\end{array}$ & & $\begin{array}{l}.272^{* * *} \\
(.092)\end{array}$ & & $\begin{array}{l}.185^{* *} \\
(.076)\end{array}$ \\
\hline Statutory Tax Rate & & $\begin{array}{c}-.842^{* * *} \\
(.281)\end{array}$ & & $\begin{array}{l}-.298 \\
(.265)\end{array}$ & & $\begin{array}{r}-.487^{*} \\
(.275)\end{array}$ & & $\begin{array}{l}.037 \\
(.243)\end{array}$ \\
\hline $\begin{array}{l}\text { Year Dummies } \\
\text { Country Dummies } \\
\text { Industry Dummies }\end{array}$ & $\sqrt{ }$ & $\begin{array}{l}\sqrt{ } \\
\sqrt{ } \\
\sqrt{ }\end{array}$ & $\sqrt{ }$ & $\begin{array}{l}\sqrt{ } \\
\sqrt{ } \\
\sqrt{ }\end{array}$ & $\sqrt{ }$ & $\begin{array}{l}\sqrt{ } \\
\sqrt{ } \\
\sqrt{ }\end{array}$ & $\sqrt{ }$ & $\begin{array}{l}\sqrt{ } \\
\sqrt{ } \\
\sqrt{ }\end{array}$ \\
\hline \# Observations & 78,012 & 74,272 & 76,706 & 72,696 & 72,121 & 68,707 & 71,242 & 67,564 \\
\hline \# MNE-Groups & 14,785 & 14,368 & 14,303 & 13,855 & 13,607 & 13,239 & 13,240 & 12,843 \\
\hline Adjusted $R^{2}$ & .8161 & .8248 & .8359 & .8422 & .6596 & .6858 & .5182 & .5442 \\
\hline
\end{tabular}

Notes:

Heteroscedasticity robust standard errors adjusted for group clusters in parentheses.

$*,{ }^{*},{ }^{* *}$ indicates significance at the $10 \%, 5 \%, 1 \%$ level. The observational units are profit-making multinational parent firms and multinational subsidiaries. A group-fixed-effect is set for belonging to a MNE-group. The abbreviation PBT stands for Profit before Tax. Parent Dummy is a dummy variable set to 1 if an observational unit is a parent firm and set to 0 if it is a subsidiary. Log Age is the natural logarithm (Log) of the firm age in years. Log (Cost Employees per Sales) is the natural logarithm of the cost of employees per sales. 56 industry dummies (NACE Rev.1 2-digit level) and 27 country dummies are included where indicated. Adjusted $R^{2}$ values are calculated from a dummy variables regression equivalent to the fixed-effects model. 


\begin{tabular}{|c|c|c|c|c|c|c|c|c|}
\hline \multicolumn{9}{|c|}{$\begin{array}{c}\text { Table 8: Robustness Check - Parents vs. Domestic Subsidiaries } \\
\text { OLS Group-Fixed-Effects, Panel 1999-2006 }\end{array}$} \\
\hline Dependent Variable & \multicolumn{2}{|c|}{ Log PBT } & \multicolumn{2}{|c|}{$\begin{array}{l}\text { Log EBIT } \\
\end{array}$} & \multicolumn{2}{|c|}{$\begin{array}{l}\text { Log(PBT p.Sales) } \\
\end{array}$} & \multicolumn{2}{|c|}{ Log(EBIT p.Sales) } \\
\hline Explanatory Variables: & (1) & (2) & (3) & (4) & $(5)$ & $(6)$ & $(7)$ & (8) \\
\hline Parent Dummy & $\begin{array}{l}.360^{* * *} \\
(.011)\end{array}$ & $\begin{array}{l}.303^{* * *} \\
(.023)\end{array}$ & $\begin{array}{l}.084^{* * *} \\
(.012)\end{array}$ & $\begin{array}{l}.252^{* * *} \\
(.022)\end{array}$ & $\begin{array}{l}.463^{* * *} \\
(.011)\end{array}$ & $\begin{array}{l}.229^{* * *} \\
(.022)\end{array}$ & $\begin{array}{l}.189^{* * *} \\
(.010)\end{array}$ & $\begin{array}{l}.128^{* * *} \\
(.019)\end{array}$ \\
\hline Log (Fixed Assets) & $\begin{array}{l}.253^{* * *} \\
(.004)\end{array}$ & $\begin{array}{l}.250^{* * *} \\
(.004)\end{array}$ & $\begin{array}{l}.222^{* * * *} \\
(.004)\end{array}$ & $\begin{array}{l}.220^{* * *} \\
(.004)\end{array}$ & $\begin{array}{c}-.290^{* * *} \\
(.005)\end{array}$ & $\begin{array}{c}-.229^{* * *} \\
(.005)\end{array}$ & $\begin{array}{c}-.172^{* * *} \\
(.004)\end{array}$ & $\begin{array}{c}-.136^{* * *} \\
(.004)\end{array}$ \\
\hline Log (Cost Employees) & $\begin{array}{l}.362^{* * *} \\
(.004)\end{array}$ & $\begin{array}{l}.376^{* * *} \\
(.005)\end{array}$ & $\begin{array}{l}.460^{* * * *} \\
(.005)\end{array}$ & $\begin{array}{l}.443^{* * *} \\
(.005)\end{array}$ & & & & \\
\hline $\begin{array}{l}\text { Log (Fixed Assets } \\
\text { per Sales) }\end{array}$ & & & & & $\begin{array}{l}.488^{* * *} \\
(.005)\end{array}$ & $\begin{array}{l}.408^{* * *} \\
(.006)\end{array}$ & $\begin{array}{l}.295^{* * *} \\
(.004)\end{array}$ & $\begin{array}{l}.242^{* * *} \\
(.005)\end{array}$ \\
\hline $\begin{array}{r}\text { Log (Cost Employees } \\
\text { per Sales) }\end{array}$ & & & & & $\begin{array}{c}-.042^{* * *} \\
(.006)\end{array}$ & $\begin{array}{c}-.055^{* * *} \\
(.007)\end{array}$ & $\begin{array}{c}-.161^{* * *} \\
(.006)\end{array}$ & $\begin{array}{c}-.168^{* * *} \\
(.006)\end{array}$ \\
\hline Leverage Ratio & & $\begin{array}{c}-1.19^{* * *} \\
(.022)\end{array}$ & & $\begin{array}{c}-.499^{* * *} \\
(.021)\end{array}$ & & $\begin{array}{c}-1.60^{\text {*** }} \\
(.021)\end{array}$ & & $\begin{array}{c}-.961^{* * *} \\
(.019)\end{array}$ \\
\hline Log Age & & $\begin{array}{l}.074^{* * *} \\
(.006)\end{array}$ & & $\begin{array}{l}.064^{* * *} \\
(.006)\end{array}$ & & $\begin{array}{l}.015^{* *} \\
(.006)\end{array}$ & & $\begin{array}{c}-.019^{* * *} \\
(.005)\end{array}$ \\
\hline Log GDP & & $\begin{array}{c}-.075^{* * *} \\
(.025)\end{array}$ & & $\begin{array}{c}-.065^{* * *} \\
(.024)\end{array}$ & & $\begin{array}{c}-.058^{* *} \\
(.025)\end{array}$ & & $\begin{array}{l}-.040^{*} \\
(.023)\end{array}$ \\
\hline Log (GDP p.Capita) & & $\begin{array}{l}-.026 \\
(.065)\end{array}$ & & $\begin{array}{l}-.095 \\
(.059)\end{array}$ & & $\begin{array}{l}.004 \\
(.061)\end{array}$ & & $\begin{array}{l}-.061 \\
(.052)\end{array}$ \\
\hline Log Corruption & & $\begin{array}{c}-.196^{* * *} \\
(.052)\end{array}$ & & $\begin{array}{c}-.192^{* * *} \\
(.047)\end{array}$ & & $\begin{array}{c}-.265^{* * *} \\
(.051)\end{array}$ & & $\begin{array}{c}-.253^{* * *} \\
(.043)\end{array}$ \\
\hline Statutory Tax Rate & & $\begin{array}{c}-.607^{* * *} \\
(.159)\end{array}$ & & $\begin{array}{c}-.439^{* * *} \\
(.145)\end{array}$ & & $\begin{array}{l}-.281^{*} \\
(.156)\end{array}$ & & $\begin{array}{r}-.265^{* *} \\
(.131)\end{array}$ \\
\hline Year Dummies & $\sqrt{ }$ & $\sqrt{ }$ & $\sqrt{ }$ & $\sqrt{ }$ & $\sqrt{ }$ & $\sqrt{ }$ & $\sqrt{ }$ & $\sqrt{ }$ \\
\hline Industry Dummies & & $\sqrt{ }$ & & $\sqrt{ }$ & & $\sqrt{ }$ & & $\sqrt{ }$ \\
\hline \# Observations & 519,915 & 466,129 & 508,344 & 453,835 & 454,167 & 405,509 & 453,271 & 403,135 \\
\hline \# Firm-Groups & 89,241 & 84,105 & 85,856 & 80,617 & 74,266 & 69,995 & 72,938 & 68,526 \\
\hline Adjusted $R^{2}$ & .7729 & .7838 & .7931 & .8012 & .6013 & .6357 & .5136 & .5405 \\
\hline
\end{tabular}

Notes:

Heteroscedasticity robust standard errors adjusted for group clusters in parentheses.

$*^{*},{ }^{*},{ }^{* * *}$ indicates significance at the $10 \%, 5 \%, 1 \%$ level. The observational units are profit-making domestic parent firms and domestic subsidiaries. A group-fixed-effect is set for belonging to a firm-group. The abbreviation PBT stands for Profit before Tax. Parent Dummy is a dummy variable set to 1 if an observational unit is a parent firm and set to 0 if it is a subsidiary. Log Age is the natural logarithm (Log) of the firm age in years. Log (Cost Employees per Sales) is the natural logarithm of the cost of employees per sales. 88 industry dummies (NACE Rev.1 2-digit level) are included where indicated. Country dummies are not included due to no variation in the country of a parent and their subsidiary(ies) which is a condition in a fixed-effects model. Adjusted $R^{2}$ values are calculated from a dummy variables regression equivalent to the fixed-effects model. 


\begin{tabular}{|c|c|c|c|c|c|c|c|c|}
\hline \multicolumn{9}{|c|}{$\begin{array}{l}\text { Table 9: Implication - Higher Parent Tax Payments } \\
\text { OLS Group-Fixed-Effects, Panel 1999-2006 }\end{array}$} \\
\hline Dependent Variable & \multicolumn{4}{|c|}{ Log (Tax Payments) } & \multicolumn{4}{|c|}{ Log (Tax Payments per Sales) } \\
\hline Explanatory Variables: & (1) & (2) & (3) & (4) & (5) & (6) & (7) & (8) \\
\hline Parent Dummy & $\begin{array}{l}.874^{* * *} \\
(.081)\end{array}$ & $\begin{array}{l}.802^{* * *} \\
(.081)\end{array}$ & $\begin{array}{l}.656^{* * *} \\
(.082)\end{array}$ & $\begin{array}{l}.648^{* * *} \\
(.083)\end{array}$ & $\begin{array}{l}.875^{* * *} \\
(.087)\end{array}$ & $\begin{array}{l}.812^{* * *} \\
(.088)\end{array}$ & $\begin{array}{l}.637^{* * *} \\
(.088)\end{array}$ & $\begin{array}{l}.614^{* * *} \\
(.085)\end{array}$ \\
\hline Log (Fixed Assets) & $\begin{array}{l}.119^{* * *} \\
(.013)\end{array}$ & $\begin{array}{l}.120^{* * *} \\
(.012)\end{array}$ & $\begin{array}{l}.107^{* * * *} \\
(.012)\end{array}$ & $\begin{array}{l}.109^{* * *} \\
(.013)\end{array}$ & $\begin{array}{c}-.242^{* * *} \\
(.016)\end{array}$ & $\begin{array}{c}-.253^{* * *} \\
(.017)\end{array}$ & $\begin{array}{c}-.230^{* * *} \\
(.017)\end{array}$ & $\begin{array}{c}-.228^{* * *} \\
(.018)\end{array}$ \\
\hline Log (Cost Employees) & $\begin{array}{l}.562^{* * *} \\
(.019)\end{array}$ & $\begin{array}{l}.553^{* * *} \\
(.020)\end{array}$ & $\begin{array}{l}.581^{* * *} \\
(.021)\end{array}$ & $\begin{array}{l}.577^{* * *} \\
(.022)\end{array}$ & & & & \\
\hline $\begin{array}{c}\text { Log (Fixed Assets } \\
\text { per Sales })\end{array}$ & & & & & $\begin{array}{l}.325^{* *} \\
(.022)\end{array}$ & $\begin{array}{l}.341^{* * *} \\
(.023)\end{array}$ & $\begin{array}{l}.301^{* * *} \\
(.024)\end{array}$ & $\begin{array}{l}.291^{* * *} \\
(.023)\end{array}$ \\
\hline $\begin{array}{r}\text { Log (Cost Employees } \\
\text { per Sales })\end{array}$ & & & & & $\begin{array}{l}.061^{* * *} \\
(.025)\end{array}$ & $\begin{array}{l}.070^{* * *} \\
(.027)\end{array}$ & $\begin{array}{l}.055^{* *} \\
(.027)\end{array}$ & $\begin{array}{l}.048^{*} \\
(.029)\end{array}$ \\
\hline Leverage Ratio & & & $\begin{array}{c}-1.08^{* * *} \\
(.067)\end{array}$ & $\begin{array}{c}-1.07^{* * *} \\
(.068)\end{array}$ & & & $\begin{array}{c}-1.41^{* * *} \\
(.064)\end{array}$ & $\begin{array}{c}-1.39^{* * * *} \\
(.065)\end{array}$ \\
\hline Log Age & & & & $\begin{array}{l}.119^{* * *} \\
(.026)\end{array}$ & & & & $\begin{array}{l}.096^{* * *} \\
(.026)\end{array}$ \\
\hline Log GDP & & $\begin{array}{c}-2.30^{* * *} \\
(.822)\end{array}$ & $\begin{array}{c}-2.13^{* * *} \\
(.823)\end{array}$ & $\begin{array}{r}-1.89^{* *} \\
(.833)\end{array}$ & & $\begin{array}{c}-2.16^{* * *} \\
(.799)\end{array}$ & $\begin{array}{c}-1.99^{* * *} \\
(.790)\end{array}$ & $\begin{array}{r}-1.79^{* *} \\
(.800)\end{array}$ \\
\hline Log (GDP p.Capita) & & $\begin{array}{l}2.52^{* * *} \\
(.844)\end{array}$ & $\begin{array}{c}2.19^{* * *} \\
(.841)\end{array}$ & $\begin{array}{l}1.81^{* *} \\
(.857)\end{array}$ & & $\begin{array}{c}2.45^{* * *} \\
(.817)\end{array}$ & $\begin{array}{c}2.07^{* * *} \\
(.804)\end{array}$ & $\begin{array}{l}1.78^{* *} \\
(.819)\end{array}$ \\
\hline Log Corruption & & $\begin{array}{l}.079 \\
(.128)\end{array}$ & $\begin{array}{l}.122 \\
(.127)\end{array}$ & $\begin{array}{l}.122 \\
(.127)\end{array}$ & & $\begin{array}{l}.034 \\
(.129)\end{array}$ & $\begin{array}{l}.090 \\
(.126)\end{array}$ & $\begin{array}{l}.107 \\
(.127)\end{array}$ \\
\hline Statutory Tax Rate & & $\begin{array}{c}2.14^{* * *} \\
(.431)\end{array}$ & $\begin{array}{c}2.40^{* * *} \\
(.430)\end{array}$ & $\begin{array}{c}2.40^{* * *} \\
(.432)\end{array}$ & & $\begin{array}{c}2.33^{* * *} \\
(.433)\end{array}$ & $\begin{array}{c}2.72^{* * *} \\
(.429)\end{array}$ & $\begin{array}{r}2.64^{* * *} \\
(.433)\end{array}$ \\
\hline Year Dummies & $\sqrt{ }$ & $\sqrt{ }$ & $\sqrt{ }$ & $\sqrt{ }$ & $\sqrt{ }$ & $\sqrt{ }$ & $\sqrt{ }$ & $\sqrt{ }$ \\
\hline Country Dummies & & $\sqrt{ }$ & $\sqrt{ }$ & $\sqrt{ }$ & & $\sqrt{ }$ & $\sqrt{ }$ & $\sqrt{ }$ \\
\hline Industry Dummies & & & & $\sqrt{ }$ & & & & $\sqrt{ }$ \\
\hline \# Observations & 51,878 & 51,851 & 48,949 & 47,640 & 48,262 & 48,235 & 45,516 & 44,291 \\
\hline \# MNE-Groups & 9,406 & 9,405 & 9,118 & 8,923 & 8,698 & 8,697 & 8,439 & 8,269 \\
\hline Adjusted $R^{2}$ & .7692 & .7758 & .7831 & .7839 & .5392 & .5500 & .5676 & .5749 \\
\hline
\end{tabular}

Notes:

Heteroscedasticity robust standard errors adjusted for group clusters in parentheses.

$*_{, * *}, * *$ indicates significance at the $10 \%, 5 \%, 1 \%$ level. The observational units are profit-making multinational parent firms and multinational subsidiaries. A group-fixed-effect is set for belonging to a MNE-group. Parent Dummy is a dummy variable set to 1 if an observational unit is a parent firm and set to 0 if it is a subsidiary. Log Age is the natural logarithm (Log) of the firm age in years. Log (Cost Employees per Sales) is the natural logarithm of the cost of employees per sales. 53 industry dummies (NACE Rev.1 2-digit level) and 27 country dummies are included where indicated. Adjusted $R^{2}$ values are calculated from a dummy variables regression equivalent to the fixed-effects model. 


\section{References}

Barba-Navaretti, G., and T. Venables (2006): "Multinational Firms in the World Economy," Princeton University Press, Princeton New Jersey.

Becker, J., C. Fuest, And N. Riedel (2009): "Quality versus Quantity - The Composition Effect of Corporate Taxation on Foreign Direct Investment," mimeo, Oxford University Centre for Business Taxation.

Betrand, M., P. Mehta, and S. Mullainathan (2002): "Ferreting Out Tunneling: An Application to Indian Business Groups," Quarterly Journal of Economics, 117(1), 121-148.

Blinder, A. S. (2006): "Offshoring: The Next Industrial Revolution?," Foreign Affairs, 85(2), 113-128.

Brakman, S., and H. Garretsen (2008): "Foreign Direct Investment and the Multinational Enterprise," CESifo Seminar Series, The MIT Press, Cambridge Massachusetts.

Budd, J. W., J. Konings, and M. J. Slaughter (2005): "Wages and International Rent Sharing in Multinational Firms," The Review of Economics and Statistics, 87, $73-84$.

Campa, J., and L. S. Goldberg (1997): "The Evolving External Orientation of Manufacturing: A Profile of Four Countries," Federal Reserve Bank of New York Economic Policy Review, 3(2), 53-81.

Chang, E., and M. S. Taylor (1999): "Control in Multinational Corporations (MNCs): The Case of Korean Manufacturing Subsidiaries," Journal of Management, 25(4), 541-565.

Clausing, K. A. (2003): "Tax-Motivated Transfer Pricing and US Intrafirm Trade Prices," Journal of Public Economics, 87(9-10), 2207-2223.

Devereux, M. P., And G. Maffini (2007): "The Impact of Taxation on the Location of Capital, Firms and Profit: A Survey of Empirical Evidence," Oxford University Centre for Business Taxation Working Paper Series, WP 07/02, Said Business School, Oxford. 
Dischinger, M., And N. Riedel (2008): "Corporate Taxes and the Location of Intangible Assets Within Multinational Firms," Munich Economics Discussion Papers, No. 2008-14 (update), University of Munich.

Dischinger, M., And N. Riedel (2009): "The Location of Multinational Headquarters and Profit Shifting," mimeo, University of Munich, University of Oxford and CESifo Munich.

Dunning, J. H. (1977): "The Determinants of International Production," Oxford Economic Papers, 25, 289-330.

Freund, C., And D. Weinhold (2002): "The Internet and International Trade in Services," American Economic Review, 92(2), 236-240.

Hamilton, R. D., and R. J. Kashlak (1999): "National Influences on Multinational Corporation Control System Selection," Management International Review, 39(2), $167-189$.

Hanson, G. H., J. R. J. Mataloni, and M. J. Slaughter (2001): "Expansion Strategies of US Multinational Firms," in Brookings Trade Forum 2001, ed. by D. Rodrik, and S. M. Collins, pp. 245-294. Washington, DC: Brookings Institution Press.

(2005): "Vertical Production Networks in Multinational Firms," Review of Economics and Statistics, 87(4), 664-678.

Huizinga, H., and L. Laeven (2008): "International Profit Shifting Within Multinationals: A Multi-Country Perspective," Journal of Public Economics, 92(5-6), 11641182.

Hummels, D., J. Ishit, and K.-M. Yi (2001): "The Nature and Growth of Vertical Specialization in World Trade," Journal of International Economics, 54(1), 75-96.

Hummels, D., D. Rapoport, and K.-M. Yi (1998): "Vertical Specialization and the Changing Nature of World Trade," Federal Reserve Bank of New York Economic Policy Review, 4(2), 79-99.

La Porta, R., F. L. De Silanes, and A. Shleifer (1999): "Corporate Ownership Around the World," Journal of Finance, 54(2), 471-517.

O’Donnell, S. W. (2000): "Managing Foreign Subsidiaries: Agents of Headquarters, or an Interdependent Network?," Strategic Management Journal, 21, 525-548. 
Zingales, L. (2000): "In Search of New Foundations," Journal of Finance, 55(4), 1623-1653. 